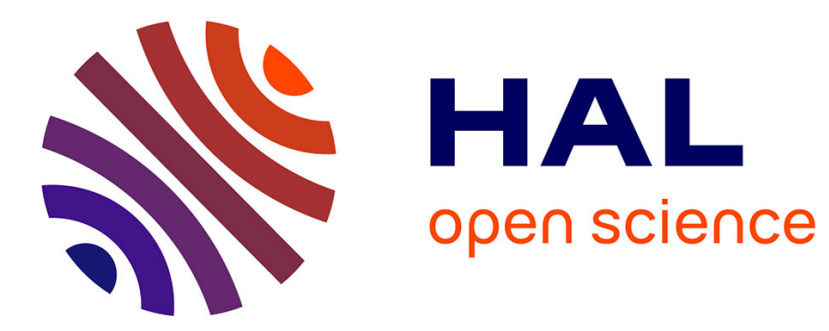

\title{
An overview of $\mathrm{CO} 2$ capture and utilization in energy models
}

Lucas Desport, Sandrine Selosse

\section{To cite this version:}

Lucas Desport, Sandrine Selosse. An overview of CO 2 capture and utilization in energy models. Resources, Conservation and Recycling, 2022, 10.1016/j.resconrec.2021.106150 . hal-03514614

\section{HAL Id: hal-03514614 \\ https://hal.science/hal-03514614}

Submitted on 6 Jan 2022

HAL is a multi-disciplinary open access archive for the deposit and dissemination of scientific research documents, whether they are published or not. The documents may come from teaching and research institutions in France or abroad, or from public or private research centers.
L'archive ouverte pluridisciplinaire HAL, est destinée au dépôt et à la diffusion de documents scientifiques de niveau recherche, publiés ou non, émanant des établissements d'enseignement et de recherche français ou étrangers, des laboratoires publics ou privés. 


\title{
An overview of $\mathrm{CO}_{2}$ capture and utilization in energy models
}

\author{
Lucas Desport $^{\mathrm{ab} *}$ and Sandrine Selosse ${ }^{\mathrm{a}}$
}

\author{
${ }^{a}$ MINES ParisTech, PSL University, CMA - Centre for Applied Mathematics, Rue C. Daunesse, 06904 Sophia \\ Antipolis, France \\ b TotalEnergies, Gas, Renewables \& Power Division, TR\&D Group, 2 place Jean Millier, 92078 Paris la \\ Défense, France \\ * corresponding author details, lucas.desport@mines-paristech.fr
}

\begin{abstract}
:
The recycling and utilization of $\mathrm{CO}_{2}$ is gaining interest in the fight against global warming. Considering $\mathrm{CO}_{2}$ not as a waste or a pollutant but as an opportunity is a concept that could prove promising for producing clean fuels in the future, as well as for producing chemicals, plastics and building materials. The extent of the benefits of Carbon Capture and Utilization (CCU) is still uncertain due to its many interactions with the rest of the energy system, and several energy models are trying to explore this area. As the global climate issue becomes an urgent policy priority, the scientific community is helping decision-makers choose the optimal technologies to successfully meet climate targets and decarbonize society. This paper reviews energy models that represent CCU as a decarbonization solution in an effort to understand and identify knowledge and modeling gaps. The results first show that $\mathrm{CO}_{2}$ utilization is still poorly represented, and that when it is, it is rarely fully integrated. The conversion of $\mathrm{CO}_{2}$ into fuels or chemicals is by far the most modeled of all the options CCU encompasses, while other key technologies for the decarbonization of the industry sector are barely considered. We discuss current CCU modeling methods and provide recommendations for future modelers who want to implement this set of technologies in their models. Additionally, we discuss the socio-economic drivers and barriers that could support or discourage the deployment of CCU in the future energy mix.
\end{abstract}

Keywords: $\mathrm{CCU}, \mathrm{CO}_{2}$ utilization, energy modeling, energy transition

\section{Highlights:}

- We review energy models including CCU as a mitigation alternative.

- CCU is rarely considered in energy models, notably in global models.

- Energy models focus on the conversion of $\mathrm{CO}_{2}$ into fuels and chemicals.

- Several recommendations are addressed to energy modelers seeking for modeling CCU.

\section{List of abbreviations:}

$\begin{array}{ll}\text { BECCS } & \text { Bio-energy with Carbon Capture and Storage } \\ \text { BU } & \text { Bottom-up } \\ \text { CapEx } & \text { Capital Expenditure } \\ \text { CCS } & \text { Carbon Capture and Storage }\end{array}$




$\begin{array}{ll}\text { CCU } & \text { Carbon Capture and Utilization } \\ \text { CCUS } & \text { Carbon Capture Utilization and Storage } \\ \text { CES } & \text { Constant Elasticity of Substitution } \\ \text { CGE } & \text { Computable General Equilibrium } \\ \text { CO }_{2} & \text { Carbon dioxide } \\ \text { DAC } & \text { Direct Air Capture } \\ \text { EOR } & \text { Enhanced Oil Recovery } \\ \text { ESM } & \text { Energy System Model } \\ \text { ETP } & \text { Energy Technology Perspective } \\ \text { GDP } & \text { Gross Domestic Product } \\ \text { GHG } & \text { Greenhouse Gas } \\ \text { H } & \text { Dihydrogen } \\ \text { IAM } & \text { Integrated Assessment Model } \\ \text { IEA } & \text { International Energy Agency } \\ \text { LCA } & \text { Life Cycle Assessment } \\ \text { MEA } & \text { Monoethanolamine } \\ \text { OpEx } & \text { Operational Expenditure } \\ \text { PSA } & \text { Pressure Swing Adsorption } \\ \text { PtG } & \text { Power-to-Gas } \\ \text { PtL } & \text { Power-to-Liquids } \\ \text { PZ } & \text { Piperazine } \\ \text { R\&D } & \text { Research \& Development } \\ \text { TD } & \text { Top-down } \\ \text { TEA } & \text { Techno-economic Assessment } \\ \text { TIMES } & \text { The Integrated MARKAL-EFOM System } \\ \text { TRL } & \text { Technology Readiness Level } \\ \text { VCM } & \text { Value Chain Model } \\ \text { VSA } & \text { Vacuum Swing Adsorption } \\ & \end{array}$

\section{Introduction}

Global climate change and its consequences are threatening our societies due to our carbon-intensive lifestyles. In the future we will face water scarcity, starvation, ocean elevation, and biodiversity decline (IPCC, 2018), especially if we do not orient towards a decarbonized economy, hence the need to transition to clean energy sources. Under the Paris Agreement, to date, the European Union (European Commission, 2016), China (Climate Action Tracker, 2020), Japan (United Nations, 2020), South Korea (Gerresten, 2020) and New Zealand (Timperley, 2020), have declared their ambition to reach carbon neutrality by 2050, or 2060 for China. To achieve this goal, governments around the world are working to define and propose sustainable pathways through carbon neutrality, which can be determined and assessed by energy models.

Meeting climate commitments involves reducing emissions of current assets through energy efficiency, demand-side measures, emissions avoidance, and greenhouse gases (GHGs) removal. This picture is easy to draw but needs to be assessed in terms of economic implications, environmental impacts, and technical feasibility. Hence, the research community is working to investigate various 
future pathways by designing energy models, such as Integrated Assessment Models (IAMs), representing the functioning of energy systems and the future transformations of energy supply when these systems are subject to a climate policy. The modeling community has been particularly prolific in recent years as, notably, it is now acknowledged that we should massively electrify our energy system and rely on negative emissions to offset the pollution we cannot abate easily (IEA, 2021; IPCC, 2018; Teske, 2019). Thereby, Carbon Capture and Storage (CCS) is determinant in delivering negative emissions, either through Direct Air Capture (DAC) (Fuss et al., 2018; Hanna et al., 2021; IPCC, 2018) or bioenergy with CCS (BECCS) (Fajardy et al., 2021; Köberle, 2019; Selosse, 2019). The capture of $\mathrm{CO}_{2}$ can occur at many levels of an energy system, from energy extraction to power production, industry, and fuel generation. At all of these levels, CCS has been recognized as indispensable to reach our climate goals (Farell, 2018; IEA, 2019a; Morris et al., 2019).

It nevertheless remains uncertain how Carbon Capture and Utilization (CCU) will contribute to the global energy transition. Instead of storing $\mathrm{CO}_{2}$ underground, the molecule can be utilized to manufacture fuels, chemicals, plastics and building materials (Alper and Yuksel Orhan, 2017; Aresta et al., 2013; Huang and Tan, 2014; Mustafa et al., 2020). Today, $200 \mathrm{Mt}$ of $\mathrm{CO}_{2}$ are employed for this purpose, more than a half of it to produce urea, used as a fertilizer (IEA, 2019b). Unfortunately, most of this $\mathrm{CO}_{2}$ utilization results in $\mathrm{CO}_{2}$ emissions when the $\mathrm{CO}_{2}$-based product is finally used. However, other niche CCU applications can avoid $\mathrm{CO}_{2}$ emissions (Pérez-Fortes et al., 2016) and even deliver negative emissions (Hepburn et al., 2019). Moreover, $\mathrm{CO}_{2}$ utilization is a way to enhance $\mathrm{CO}_{2}$ that would have been captured either way, by transforming it into a valuable product. Given these two major considerations, $\mathrm{CO}_{2}$ utilization can have a significant role in climate mitigation by bringing both economic and climate benefits.

Recent literature reviews show advances in carbon dioxide utilization (Ghiat and Al-Ansari, 2021) but also reveal three major barriers to its deployment: technology readiness (Ampelli et al., 2015; Mustafa et al., 2020), high energy consumption (Alper and Yuksel Orhan, 2017; Aresta et al., 2013; Huang and Tan, 2014) and high costs (Centi et al., 2020; Hepburn et al., 2019). Undoubtedly, these reviews gather information that can be extracted and implemented in energy models to represent a CCU chain and assess whether it can play a significant role in the future energy transition. Nevertheless, what energy models show about the contribution of CCU to climate change mitigation is neither clear nor subject to consensus. Indeed, the estimated potential of $\mathrm{CO}_{2}$ captured and used globally varies from a few hundred megatons (IEA, 2019b, p. 2) to several gigatons (Kätelhön et al., 2019).

In view of the great variability of CCU's potential role in the future, it is unclear to what extent this set of technologies can help us mitigate climate change. Butnar et al. (2020) reviewed the role of CCU and CCS in the results of European energy models. They provide a detailed description of the potentials and mitigation impacts of CCU in European decarbonization scenarios and conclude that there is no clear future for CCU, either in terms of potential or role. They also argue that global energy models poorly represent $\mathrm{CO}_{2}$ utilization. Another review reports the state-of-the-art of the programming tools and pinch analysis tools representing CCUS value chains, with a special focus on each branch of the value chain (Tapia et al., 2018). The authors also perform a bibliometric analysis of CCUS, revealing the growing interest for this set of technologies in the research community. This article mainly addresses operations planning of CCUS rather than assessing potentials and roles of $\mathrm{CO}_{2}$ utilization through energy models and IAMs.

Although CCU is a major issue for the future, the modeling of this technology is limited in the literature. In an attempt to constitute a milestone for further modelings of $\mathrm{CCU}$, the present paper describes the state-of-the-art of $\mathrm{CO}_{2}$ utilization representation in energy models. The aim is to analyze shortcomings and trends in CCU modeling and to understand the results models provide on $\mathrm{CO}_{2}$ utilization. We first discuss the motivations of modeling $\mathrm{CO}_{2}$ utilization and analyze the trends in CCU modeling based on our literature review (section 2). Then we analyze how CCU is currently 
modeled (section 3) before discussing the drivers of CCU and recommending best practices (section 4). We emphasize that this analysis does not focus on the results that the models return, but rather on how CCU is modeled.

\section{Literature review of $\mathrm{CO}_{2}$ utilization in energy models: motivations and trends}

Energy modeling consists in representing the energy system of a geographic zone, which can be national, regional, or global. An energy system is defined as a close system guaranteeing satisfaction of energy demand through energy production, transformation, transport, and distribution. Usually, the purpose of energy modeling is to explore multiple pathways that policymakers should consider in order to tackle climate change or to reach energy policy targets e.g. related to energy security, resource scarcity, nuclear phase-out, etc. Modelers propose new paradigms for our society to produce and consume energy in respect of our energy-climate commitments and warn of the implications and requirements of such changes. Energy models comprise different structures (Böhringer and Rutherford, 2009) - bottom-up or top-down - and resolution methods (Helgesen, 2013) optimization or simulation. Technologies such as CCU are key components of an energy model, as they behave as a means to transform energy and satisfy energy demand.

We searched the scientific literature for energy models that consider the capture and use of $\mathrm{CO}_{2}$. To do so, we browsed the ScienceDirect platform with keywords such as " $\mathrm{CO}_{2}$ utilization, $\mathrm{CO}_{2}$ conversion, energy models, modeling, CCU, Power-to-Gas and Power-to-Liquids" to find energy models taking into consideration at least one route that $\mathrm{CO}_{2}$ utilization offers. We also looked at the IAMC platform (IAMC-Documentation contributors, 2021) and systematically reviewed each global model's presentation to see whether CCU was included as an option. The only selection criterion was that energy models should consider at least one $\mathrm{CO}_{2}$ utilization route and provide sufficient detail to analyze the modeling. We examined each model in terms of:

- technology representation from capture to utilization in order to identify the origin of $\mathrm{CO}_{2}$ (process $\mathrm{CO}_{2}$, fossil $\mathrm{CO}_{2}$, atmospheric $\mathrm{CO}_{2}$ or biogenic $\mathrm{CO}_{2}$ ) and the final products made of $\mathrm{CO}_{2}$. We call "technology bricks" a stand-alone process producing an energy or material commodity such as a power plant or a $\mathrm{CO}_{2}$ conversion process;

- modeling assumptions, i.e. the consideration of carbon taxes, techno-economic assumptions of CCU technologies, technology learning, etc.;

- model type, whether Energy System Models (ESMs) or Value Chain Models (VCMs) and bottom-up (BU) or top-down (TD) (Section 3);

- geographical perimeter;

- time horizon;

- climate target;

- the parametrization, i.e. the parameters used by the modelers in the study to characterize CCU.

Table 1 describes the 22 studies that have been reviewed. Currently, energy models rarely consider CCU as a decarbonization option (Butnar et al., 2020), yet their representation in energy models is vital for decision-makers to determine whether this technology set should be deployed extensively, as well as its role in mitigating climate and reducing the cost of carbon capture (Mac Dowell et al., 2017). Nonetheless, the few studies focusing on the use of $\mathrm{CO}_{2}$ in energy models are mainly produced in the context of $\mathrm{CO}_{2}$ emissions reduction, and particularly in the context of the Paris Agreement. Sometimes, $\mathrm{CO}_{2}$ utilization is seen and modeled as a commercial opportunity (IEA, 2019b; Tapia et al., 2014), i.e. once $\mathrm{CO}_{2}$ is captured it can be employed to produce goods, and this is the prime interest of modeling. Including $\mathrm{CO}_{2}$ utilization as a novel option for energy models, researchers try to establish new paradigms, especially for the transport sector since the most targeted $\mathrm{CO}_{2}$ utilization is 
fuel manufacture. The authors' motive is to valorize the captured $\mathrm{CO}_{2}$ rather than store it underground permanently. Thus, energy modeling seeks to determine the following key information:

\section{- The potential of $\mathrm{CO}_{2}$ utilization}

Usually, the potential deployment of $\mathrm{CO}_{2}$ utilization is expressed in terms of megatons of $\mathrm{CO}_{2}$ utilized per year. It can also be evaluated by the quantity of $\mathrm{CO}_{2}$-based products supplying demand. For example, Blanco et al. (2018) explored under various policy scenarios the quantity of $\mathrm{CO}_{2}$ to be converted into synfuels to ensure European energy demand in the future.

\section{- The energy system transformation}

Utilizing $\mathrm{CO}_{2}$ instead of venting is an appealing solution to mitigate climate change but can have strong impacts on the overall energy system, such as the required renewable power generation (Bazzanella and Ausfelder, 2017), the impact on land (Gabrielli et al., 2020) and water scarcity (Dutta et al., 2017). This closely depends on the deployment rate of $\mathrm{CO}_{2}$ utilization capacities to be installed: all of these impacts are linked and related to the quantity of $\mathrm{CO}_{2}$ needed. Van Vliet et al. (2011) performed a complete study of the impact of alternative fuels (e-fuels included) on the transportation sector.

\section{- Environmental impact assessment}

Authors also explore the potential environmental impacts of CCU, such as pollutants and human health impacts. This kind of information is mostly determined through life-cycle assessments (Assen and Bardow, 2014; Cuéllar-Franca and Azapagic, 2015), and can also be evaluated by energy models.

\section{- Economic impact assessment}

Comprehending the impacts of CCU on the economy is crucial. Indeed, the transformation of the energy system is not just about $\mathrm{CO}_{2}$ emissions reductions and environmental concerns; it also has collateral impacts on the economy, namely employment, fuel prices, electricity prices, consumption, and gross domestic product (GDP). These factors would condition whether a technology successfully enters the market, hence the importance of bringing this topic into the debate.

Ultimately, the purpose of modeling $\mathrm{CO}_{2}$ utilization is to advise decision-makers on best practices to achieve energy transition by considering a number of side effects on other centers of interest such as environmental and socio-economic impacts. 
Table 1: Overview of CCU modeling methods in energy modeling studies

\begin{tabular}{|c|c|c|c|c|c|c|c|c|c|c|c|}
\hline Author & Context & \begin{tabular}{|l} 
Model name \\
\end{tabular} & Model type & $\begin{array}{l}\text { BU vs } \\
\text { TD }\end{array}$ & Region & $\begin{array}{l}\begin{array}{l}\text { Time } \\
\text { horizon }\end{array}\end{array}$ & Climate target & $\begin{array}{l}\mathrm{lO}_{2} \\
\text { capture }\end{array}$ & $\mathrm{CO}_{2}$ utilization & Parametrization & Comments on the CCU modeling \\
\hline $\begin{array}{l}\text { (Fasihi et al., } \\
\text { 2017) }\end{array}$ & $\begin{array}{l}\text { The aim is to take advantage of the } \\
\text { Maghreb's potential for solar and wind } \\
\text { power generation to manufacture fuels } \\
\text { with atmospheric } \mathrm{CO}_{2} \text { and green } \mathrm{H}_{2} \text { to } \\
\text { satisfy European fuel demand. }\end{array}$ & $\begin{array}{l}\text { Hourly Basis } \\
\text { Model }\end{array}$ & Supply Chain & $\mathrm{BU}$ & $\begin{array}{l}\text { Maghreb } \\
\text { and } \\
\text { Europe }\end{array}$ & 2050 & NZE emission & DAC & $\begin{array}{l}\text { Power-to- } \\
\text { Gas;Power-to- } \\
\text { Liquids }\end{array}$ & $\begin{array}{l}\text { CapEx and } \\
\text { OpEx; Lifetime; } \\
\text { Efficiencies; } \\
\text { Other specific } \\
\text { technical } \\
\text { parameters }\end{array}$ & $\begin{array}{l}\text { The capture of } \mathrm{CO}_{2} \text { is ensured only by DAC units } \\
\text { fed with renewable electricity and heat. The } \\
\text { utilizizion of } \mathrm{CO}_{2} \text { begins with its stransformation int } \\
\text { fuel products along with renewable hydrogen. The } \\
\text { study provides two very detailed block-flow } \\
\text { diagrams to represent the utilization units, } \\
\text { production, storage, and delivery of synfuels. The } \\
\text { results rely on techno-economic assumptions that } \\
\text { might be debatable for DAC. }\end{array}$ \\
\hline $\begin{array}{l}\text { (Farfan et al., } \\
\text { 2019) }\end{array}$ & $\begin{array}{l}\text { This study looks at capturing } \mathrm{CO}_{2} \\
\text { emissions from cement plants to produce } \\
\text { fuels and assesses the potential of } \mathrm{CCU} \\
\text { to mitigate cement factory emissions. The } \\
\text { purpose is to estimate the quantitity of } \mathrm{CO}_{2} \\
\text { captured from the cement industry that } \\
\text { could be used to make synthetic fuels. }\end{array}$ & N/A & Supply Chain & $\mathrm{BU}$ & World & 2050 & $\begin{array}{l}\text { Different } \\
\text { scenarios 1) } \\
\text { Cement } \\
\text { Sustanable } \\
\text { Intiaitive target } \\
\text { 2) 42.9\% } \\
\text { emissions } \\
\text { reduction 3) Only } \\
\text { process-related } \\
\text { emissions remain }\end{array}$ & $\begin{array}{l}\text { Cement } \\
\text { plants }\end{array}$ & $\begin{array}{l}\text { Power-to- } \\
\text { Gas;Power-to- } \\
\text { Liquids }\end{array}$ & $\begin{array}{l}\text { Carbon capture } \\
\text { efficiencies; } \\
\text { Energy needs; } \\
\text { Emissions } \\
\text { levels per ton of } \\
\text { cement; PtX } \\
\text { energy and } \\
\text { material flows }\end{array}$ & $\begin{array}{l}\text { The authors simulate the potential of the cement } \\
\text { industry in supplying } \mathrm{CO}_{2} \text { for fuel mannfacture. } \\
\text { Non-transparent modeleling of } \mathrm{CO}_{2} \text { utilizatiotion with } \\
\text { little techno-economic information about Power-to- } \\
\mathrm{X} \text { processes. The authors provide some referencese } \\
\text { concerning the capture technologies, namely carbon } \\
\text { looping and amine scrubbing. }\end{array}$ \\
\hline $\begin{array}{l}\text { (Kätelhön et al., } \\
\text { 2019) }\end{array}$ & $\begin{array}{l}\text { The idea is to assess the potential of } \mathrm{CO}_{2} \\
\text { to replace hydrocarbon feedstocks for the } \\
\text { chemical industry. The authors propose } \\
\text { new paradigms for the chemical industry } \\
\text { across three scenarios. }\end{array}$ & \begin{tabular}{|l|} 
Technology \\
Choice Model
\end{tabular} & $\begin{array}{l}\text { Energy } \\
\text { system }\end{array}$ & $\mathrm{BU}$ & World & 2030 & $\begin{array}{l}\text { Decarbonization } \\
\text { of the chemical } \\
\text { industry }\end{array}$ & $\begin{array}{l}\text { Industry;D } \\
\text { AC }\end{array}$ & $\begin{array}{l}\text { Power-to- } \\
\text { Gas;Methanol; } \\
\text { Olefins;Other } \\
\text { chemicals }\end{array}$ & $\begin{array}{l}\text { Energy } \\
\text { consumption; } \\
\text { Efficiencies; } \\
\text { Environmental } \\
\text { footprints; }\end{array}$ & $\begin{array}{l}\text { This optimization is of a particular kind since it doe } \\
\text { not minimize the total annual cost, but rather the } \\
\text { GHG emissions of the system. The } \mathrm{CO}_{2} \text { supply is } \\
\text { ensured by high-purity industrial processes and } \\
\text { DAC. Two main assumptions are made considering } \\
\text { the carbon footprints of CCU plants involving a } \\
\text { High-TRL scenario and a Low-TRL scenario. } \\
\text { Technology data is summarized in open-access } \\
\text { documentation, mainly from Ecoinvent and } \\
\text { IHSdatabases. }\end{array}$ \\
\hline
\end{tabular}




\begin{tabular}{|c|c|c|c|c|c|c|c|c|c|c|c|}
\hline $\begin{array}{l}\text { (Bazzanella and } \\
\text { Ausfelder, 2017) }\end{array}$ & $\begin{array}{l}\text { This study analyzes how the European } \\
\text { chemical industry could take advantage } \\
\text { of new technologies to decarbonize its } \\
\text { activity. The authors identify promising } \\
\text { low-carbon technologies considering } \\
\text { their potential impact on } \mathrm{CO}_{2} \text { emissions } \\
\text { reduction, costs, technical performances } \\
\text { and barriers. }\end{array}$ & \begin{tabular}{|l|} 
No name \\
\end{tabular} & $\begin{array}{l}\text { Energy } \\
\text { system }\end{array}$ & $\mathrm{BU}$ & Europe & 2050 & $\begin{array}{l}\text { Decarbonization } \\
\text { of the chemical } \\
\text { industry }\end{array}$ & $\begin{array}{l}\text { Power } \\
\text { plants;Ind } \\
\text { ustry }\end{array}$ & $\begin{array}{l}\text { Urea;Methanol; } \\
\text { Power-to- } \\
\text { Gas;Power-to- } \\
\text { Liquids;Plastics }\end{array}$ & $\begin{array}{l}\text { Energy and } \\
\text { material flows; } \\
\text { Environmental } \\
\text { impacts; CapEx } \\
\text { and OpEx }\end{array}$ & $\begin{array}{l}\text { The modeling of CCU is based on techno-economic } \\
\text { parameters of processes with their related material } \\
\text { and energy flows, as well as their environmental } \\
\text { impacts. The added value of the study is that CCU } \\
\text { routes are compared with alternative routes including } \\
\text { electrification, biomass and recycling. Many efforts } \\
\text { have been made to describe the new clean } \\
\text { production systems the authors consider. The study } \\
\text { includes sector-coupling with energy sector and the } \\
\text { transport sector. }\end{array}$ \\
\hline (IEA, 2019c) & $\begin{array}{l}\text { Explores the implications of the } \\
\text { unavailability of } \mathrm{CO}_{2} \text { storage on the } \\
\text { energy sector, including the need for } \mathrm{CO}_{2} \\
\text { utilization. Potential and opportunities } \\
\text { are assessed in three different scenarios } \\
\text { 1) Clean Technology Scenario (CTS) 2) } \\
\text { Low Carbon Storage (LCS) and 3) } \\
\text { Reference Technology Scenario (RCS). } \\
\text { In the CTS and LCS, the focus is on the } \\
\text { industry sector. }\end{array}$ & \begin{tabular}{|l} 
IEA Energy \\
Technology \\
Perspectives \\
model
\end{tabular} & $\begin{array}{l}\text { Energy } \\
\text { system }\end{array}$ & $\mathrm{BU}$ & World & 2060 & $\begin{array}{l}75 \% \text { cut in } \mathrm{CO}_{2} \\
\text { emissions } \\
\text { compared to } \\
2017 \text { levels }\end{array}$ & $\begin{array}{l}\text { Industry;D } \\
\text { AC;Power } \\
\text { plants;Bio } \\
\text { mass;Hydr } \\
\text { ogen }\end{array}$ & $\begin{array}{l}\text { Urea;Methanol; } \\
\text { Concrete;Other } \\
\text { chemicals;Plasti } \\
\text { cs;Power-to- } \\
\text { Gas;Power-to- } \\
\text { Liquids }\end{array}$ & $\begin{array}{l}\text { Energy and } \\
\text { material flows; } \\
\text { Environmental } \\
\text { impacts; CapEx } \\
\text { and OpEx }\end{array}$ & $\begin{array}{l}\text { The IEA Energy Technology Perspectives (ETP) } \\
\text { model depicts new opportunities for the energy } \\
\text { system to shift from polluting production to clean } \\
\text { production. This model is thus technology-oriented } \\
\text { and yet poor assumptions are given about the } \\
\text { economics of CCU processes. The modeling is based } \\
\text { on the TIMES framework. The } \mathrm{CO}_{2} \text { tax is not } \\
\text { applied to synfuels made of biogenic } \mathrm{CO}_{2} \text {. }\end{array}$ \\
\hline $\begin{array}{l}\text { (Leonzio et al., } \\
\text { 2020) }\end{array}$ & $\begin{array}{l}\text { This study takes place in the context of a } \\
\text { UK energy transition that aims to abate } \\
6.4 \text { Mton of } \mathrm{CO}_{2} \text { per year. The authors } \\
\text { consider both storage and utilization and } \\
\text { their related role in abating } \mathrm{CO}_{2} \\
\text { emissions. }\end{array}$ & No name & Supply Chain & $\mathrm{BU}$ & UK & 2030 & $\begin{array}{l}6.4 \mathrm{MtCO}_{2} / \mathrm{yr} \\
\text { emission } \\
\text { reduction }\end{array}$ & $\begin{array}{l}\text { MEA } \\
\text { absorption } \\
\text {;PZ } \\
\text { absorption }\end{array}$ & $\begin{array}{l}\text { Methanol;Powe } \\
\text { r-to- } \\
\text { Gas;Polyuretha } \\
\text { ne;Horticulture; } \\
\text { Concrete;Calciu } \\
\text { m carbonate }\end{array}$ & $\begin{array}{l}\text { Production } \\
\text { costs; Capture } \\
\text { costs; Material } \\
\text { flows; Plants } \\
\text { location }\end{array}$ & $\begin{array}{l}\text { The specific constraints of } \mathrm{CCU} \text { modeling are made } \\
\text { explicit. For example, } \mathrm{CO}_{2} \text { cannot be sent to multiple } \\
\text { storage sites, storage capacitit is limited, minimum } \\
\mathrm{CO}_{2} \text { abatementht etc. A detailed description of how } \\
\text { the model works is provided. A carbon tax of } 80 \\
\text { euros per ton is assumed. }\end{array}$ \\
\hline $\begin{array}{l}\text { (Leonzio et al., } \\
\text { 2019) }\end{array}$ & $\begin{array}{l}\text { A model is designed to assess the } \\
\text { potential of carbon dioxide utilization } \\
\text { and storage in Germany to satisfy } \\
\text { methanol demand. }\end{array}$ & \begin{tabular}{|l} 
No name \\
\end{tabular} & Supply Chain & $\mathrm{BU}$ & Germany & 2030 & $\begin{array}{l}160 \mathrm{MtCO}_{2} / \mathrm{yr} \\
\text { emission } \\
\text { reduction }\end{array}$ & $\begin{array}{l}\text { MEA } \\
\text { absorption } \\
\text {;PZ } \\
\text { absorption } \\
\text {;Membran } \\
\text { es;PSA;V } \\
\text { SA }\end{array}$ & $\begin{array}{l}\text { Hydrogen;Meth } \\
\text { anol }\end{array}$ & $\begin{array}{l}\text { Capture costs; } \\
\text { Material flows; } \\
\text { Plants location }\end{array}$ & \\
\hline $\begin{array}{l}\text { (Leonzio and } \\
\text { Zondervan, 2020) }\end{array}$ & $\begin{array}{l}\text { The model is designed to represent } \\
\text { CCUS supply chains and define their } \\
\text { framework to significantly reduce } \mathrm{CO}_{2} \\
\text { emissions whilst minimizing total costs. } \\
\text { The model is built for the Italian regions. }\end{array}$ & \begin{tabular}{|l|} 
No name \\
\end{tabular} & Supply Chain & $\mathrm{BU}$ & Italy & 2030 & $\begin{array}{l}77 \mathrm{MtCO}_{2} / \mathrm{yr} \\
\text { emission } \\
\text { reduction }\end{array}$ & $\begin{array}{l}\text { MEA } \\
\text { absorption } \\
\text {;PZ } \\
\text { absorption } \\
\text {;Membran } \\
\text { es;PSA;V } \\
\text { SA }\end{array}$ & Power-to-Gas & $\begin{array}{l}\text { Capture costs; } \\
\text { Material flows; } \\
\text { Methane } \\
\text { production } \\
\text { costs; Plants } \\
\text { location; } \\
\text { Economic } \\
\text { incentives for } \\
\text { PtG processes }\end{array}$ & \\
\hline
\end{tabular}




\begin{tabular}{|c|c|c|c|c|c|c|c|c|c|c|c|}
\hline $\begin{array}{l}\text { (Blanco et al., } \\
\text { 2018a) }\end{array}$ & $\begin{array}{l}\text { The authors utilize a bottom-up model to } \\
\text { evaluate the potential of methanation in } \\
\text { the EU energy transition. }\end{array}$ & \begin{tabular}{|l} 
JRC-EU- \\
TIMES
\end{tabular} & $\begin{array}{l}\text { Energy } \\
\text { system }\end{array}$ & BU & Europe & 2050 & $\begin{array}{l}80 \text { to } 95 \% \mathrm{CO}_{2} \\
\text { reduction by } \\
2050 \text { (vs. 1990) }\end{array}$ & $\begin{array}{l}\text { Industry;D } \\
\text { AC;Power } \\
\text { plants;Bio } \\
\text { mass;Hydr } \\
\text { ogen }\end{array}$ & Power-to-Gas & $\begin{array}{l}\text { CapEx and } \\
\text { Optx; } \\
\text { Efficiencies; } \\
\text { Availability; } \\
\text { Lifespan; } \\
\text { Energy and } \\
\text { material flows }\end{array}$ & $\begin{array}{l}\text { TIMES representation of technology bricks. No } \\
\text { variable costs are represented as they are mainly } \\
\text { supported by } \mathrm{CO}_{2} \text { feedstoctock of methanation } \\
\text { processes. The modelers provide } 3 \text { different } \\
\text { scenarios for PtG costs and } 8 \text { different policy } \\
\text { scenarios of which two with no } \mathrm{CO}_{2} \text { storage } \\
\text { available. A v variable } \mathrm{CO}_{2} \text { price is considered. }\end{array}$ \\
\hline $\begin{array}{l}\text { (Blanco et al., } \\
\text { 2018b) }\end{array}$ & $\begin{array}{l}\text { The authors utilize a bottom-up model to } \\
\text { evaluate the potential of PtL in the } \\
\text { European energy transition. }\end{array}$ & \begin{tabular}{|l|} 
JRC-EU- \\
TIMES
\end{tabular} & $\begin{array}{l}\text { Energy } \\
\text { system }\end{array}$ & BU & Europe & 2050 & $\begin{array}{l}80 \text { to } 95 \% \mathrm{CO}_{2} \\
\text { reduction by } \\
2050 \text { (vs. 1990) }\end{array}$ & $\begin{array}{l}\text { Industry;D } \\
\text { AC;Power } \\
\text { plants;Bio } \\
\text { mass;Hydr } \\
\text { ogen }\end{array}$ & $\begin{array}{l}\text { Power-to- } \\
\text { Liquids;Methan } \\
\text { ol }\end{array}$ & $\begin{array}{l}\text { CapEx and } \\
\text { OpEx; } \\
\text { Efficiencies; } \\
\text { Availability; } \\
\text { Lifespan; } \\
\text { Energy and } \\
\text { material flows }\end{array}$ & $\begin{array}{l}\text { TIMES representation of technology bricks with a } \\
\text { high level of detail ( } 23 \text { processes). The modelers } \\
\text { provide different scenarios for } \mathrm{PtL} \text { costs. A variable } \\
\mathrm{CO}_{2} \text { price is considered. }\end{array}$ \\
\hline (Dutta et al., 2017) & $\begin{array}{l}\text { The proposed model is employed to } \\
\text { assess the contribution of } \mathrm{CO}_{2} \text { utililization } \\
\text { to produce power and chemicals. Instioad } \\
\text { of minimizing the total cost, they } \\
\text { maximizize } \mathrm{CO}_{2} \text { avoidance. Three } \\
\text { scenarios considering different renewable } \\
\mathrm{H}_{2} \text { availability are studied. }\end{array}$ & \begin{tabular}{|l|} 
No name \\
\end{tabular} & $\begin{array}{l}\text { Energy } \\
\text { system }\end{array}$ & $\mathrm{BU}$ & World & Not stated & $\begin{array}{l}1 \text { to } 59 \% \mathrm{CO}_{2} \\
\text { emissions } \\
\text { reduction } \\
\text { compared to } \\
2013 \text { level }\end{array}$ & $\mathrm{N} / \mathrm{A}$ & $\begin{array}{l}\text { Hydrogen;DME } \\
\text {;Methanol;Olefi } \\
\text { ns;Urea }\end{array}$ & $\begin{array}{l}\text { Environmental } \\
\text { impacts }\end{array}$ & $\begin{array}{l}\text { The model is fed with } \mathrm{CO}_{2} \text { avoidance inputs that } \\
\text { reflect the } \mathrm{CO}_{2} \text { that would not be emitted into the } \\
\text { atmosphere if the alternative CCU option were } \\
\text { chosen by the model. The total amount of } \mathrm{CO}_{2} \\
\text { avoided resulting from the opptimizizaion is evaluated } \\
\text { considering the } \mathrm{CO}_{2} \text { emission factors of remaining } \\
\text { fuels. Three scenarios are discussed including with } \\
\text { unlimited renewable hydrogen. Costs are not } \\
\text { considered since the objective function is to } \\
\text { maximize } \mathrm{CO}_{2} \text { avoidance. }\end{array}$ \\
\hline $\begin{array}{l}\text { (Williams et al., } \\
\text { 2021) }\end{array}$ & $\begin{array}{l}\text { The United States is supposed to reach } \\
\text { carbon neutrality by mid-century } \\
\text { following IPCC recommendations. Two } \\
\text { models are developed and utilized to } \\
\text { model the entire US and industrial } \\
\text { system. One is capable of making } \\
\text { technology choices at the demand-side } \\
\text { level. The other addresses the sequential } \\
\text { hourly variation of renewable energy } \\
\text { over a sampling of representative days to } \\
\text { find the lowest cost solution to to } \\
\text { decarbonize energy supply. }\end{array}$ & \begin{tabular}{|l} 
EnergyPATH \\
WAYS \& \\
RIO
\end{tabular} & $\begin{array}{l}\text { Energy } \\
\text { system }\end{array}$ & $\mathrm{BU}$ & USA & 2050 & $\begin{array}{l}\text { Decarbonation } \\
\text { target }\end{array}$ & $\begin{array}{l}\text { Industry;D } \\
\text { AC;Bioma } \\
\text { ss }\end{array}$ & $\begin{array}{l}\text { Power-to- } \\
\text { Liquids;Power- } \\
\text { to-Gas }\end{array}$ & $\begin{array}{l}\text { CapEx and } \\
\text { OpEx: } \\
\text { Efficiencies; } \\
\text { Availability; } \\
\text { Lifiespan; } \\
\text { Energy and } \\
\text { material flows }\end{array}$ & $\begin{array}{l}\text { The modeling of } \mathrm{CCU} \text { is achieved in a typical } \mathrm{BU} \\
\text { fashion. It comprises the capture of } \mathrm{CO}_{2} \text { from highly } \\
\text { concentrateds streams in industry or biogenic } \mathrm{CO}_{2} \\
\text { directly from air or biomass conversion. Then } \mathrm{CO}_{2} \text { is } \\
\text { utilized for a single purpose, i.e., to manufacture } \\
\text { fuels as energy carriers or feedstocks (e.g. for the } \\
\text { chemical industry). In most scenarios, the captured } \\
\mathrm{CO}_{2} \text { is biogenic, so the majority of manufactured } \\
\text { fuels are climate-neutral. }\end{array}$ \\
\hline 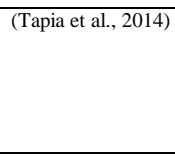 & $\begin{array}{l}\text { First-of-a-kind study working on the } \\
\text { optimal design and planning of a CCUS } \\
\text { value chain that only considers EOR as a } \\
\mathrm{CO}_{2} \text { utilizization option. }\end{array}$ & \begin{tabular}{|l|} 
No name \\
\end{tabular} & Supply Chain & $\mathrm{BU}$ & $\mathrm{N} / \mathrm{A}$ & Not stated & No stated target & $\mathrm{N} / \mathrm{A}$ & EOR & OpEx; Lifespan & $\begin{array}{l}\text { The authors run an optimization model maximizing } \\
\text { the profit that can be generated from EOR and } \\
\text { provide a description of its basic framework. Data } \\
\text { about operation costs are included. The study } \\
\text { focuses on the end-of-the-pipe, meaning that only } \\
\text { utilization is considered and not capture. }\end{array}$ \\
\hline (Teske, 2019) & $\begin{array}{l}\text { Global complete energy transition } \\
\text { pathways at different regional scales for a } \\
\text { decarbonized world in } 2050 \text {. }\end{array}$ & \begin{tabular}{|l} 
Global GHG \\
model \\
+TRAEM + \\
Energy \\
System \\
Model + [R]E \\
24/7
\end{tabular} & $\begin{array}{l}\text { Energy } \\
\text { system }\end{array}$ & Hybrid & World & 2100 & $\begin{array}{l}\text { Decarbonization } \\
\text { target }\end{array}$ & Biomass & $\begin{array}{l}\text { Power-to- } \\
\text { Liquids }\end{array}$ & $\begin{array}{l}\text { CapEx; } \\
\text { Efficiencies }\end{array}$ & $\begin{array}{l}\text { The modeling methodology of } \mathrm{CCU} \text { is described } \\
\text { simply but the interaction between the capture of } \\
\mathrm{CO}_{\text {, the utilization and the combination with }} \\
\text { hydrogen is not explicit. }\end{array}$ \\
\hline
\end{tabular}




\begin{tabular}{|c|c|c|c|c|c|c|c|c|c|c|c|}
\hline $\begin{array}{l}\text { (Khalili et al., } \\
\text { 2019) }\end{array}$ & $\begin{array}{l}\text { Exploration of scenarios for the } \\
\text { transportation sector in the context of the } \\
\text { Paris Agreement. The aim is to study the } \\
\text { penertation on new options in the } \\
\text { transportation sector to reach } 100 \% \\
\text { renewable by } 2050 \text {. }\end{array}$ & $\begin{array}{l}\text { No name } \\
\end{array}$ & $\begin{array}{l}\text { Energy } \\
\text { system }\end{array}$ & Hybrid & World & 2050 & $\begin{array}{l}\text { Decarbonization } \\
\text { target }\end{array}$ & N/A & $\begin{array}{l}\text { Power-to- } \\
\text { Liquids;Power- } \\
\text { to-Gas }\end{array}$ & $\begin{array}{l}\text { CapEx and } \\
\text { OpEx; } \\
\text { Efficiencies; } \\
\text { Availability; } \\
\text { Lifespan }\end{array}$ & $\begin{array}{l}\text { The modeling of the transport sector is very concise } \\
\text { and identifies great potential for rail, marine and } \\
\text { aviation sectors to be decarbonized through synfuels, } \\
\text { while road transport is more likely to be } \\
\text { decarbonized by electric and hydrogen cars. The } \\
\text { modeling of new opportunities is mainly achieved by } \\
\text { feeding the model with new processes and their } \\
\text { related costs, efficiencies and environmental } \\
\text { impacts. }\end{array}$ \\
\hline $\begin{array}{l}\text { (Bogdanov et al., } \\
\text { 2019) }\end{array}$ & $\begin{array}{l}\text { Modeling of the energy sector and its } \\
\text { interactions with the transport sector and } \\
\text { industry to capture the interest of sector } \\
\text { coupling to reach a climate-eneutral } \\
\text { European energy system. Capture } \\
\text { technologieis are not allowed for the } \\
\text { power sector but Power-to-X solutions } \\
\text { can be addressed for the transport sector } \\
\text { with atmospheric } \mathrm{CO}_{2} \text {. }\end{array}$ & $\begin{array}{l}\text { LUT Energy } \\
\text { System } \\
\text { Transition } \\
\text { Model }\end{array}$ & $\begin{array}{l}\text { Energy } \\
\text { system }\end{array}$ & $\mathrm{BU}$ & World & 2050 & $\begin{array}{l}\text { Decarbonization } \\
\text { target }\end{array}$ & DAC & $\begin{array}{l}\text { Power-to- } \\
\text { Gas;Power-to- } \\
\text { Liquids }\end{array}$ & $\begin{array}{l}\text { CapEx and } \\
\text { OpEx; Lifespan; } \\
\text { Energy and } \\
\text { material flows; } \\
\text { Efficiencies; } \\
\text { Learning rates }\end{array}$ & 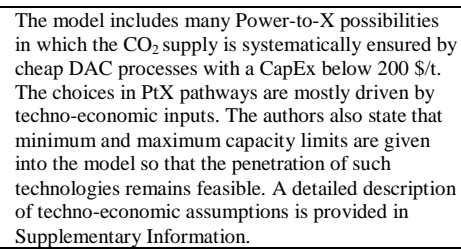 \\
\hline $\begin{array}{l}\text { (Capros et al., } \\
\text { 2019) }\end{array}$ & $\begin{array}{l}\text { Power-to-X routes are introduced into a } \\
\text { European energy model to propose } \\
\text { sustainable optimal profiles of energy } \\
\text { supply in a climate-neutral energy } \\
\text { system. }\end{array}$ & PRIMES & $\begin{array}{l}\text { Energy } \\
\text { system }\end{array}$ & $\mathrm{BU}$ & $\begin{array}{l}\text { Europe } \\
\end{array}$ & 2070 & $\begin{array}{l}80 \% \text { emission cut } \\
\text { compared to } \\
1990 \text { or climate } \\
\text { neutrality }\end{array}$ & $\begin{array}{l}\text { DAC;Pow } \\
\text { er } \\
\text { sector;Ind } \\
\text { ustry;Bio } \\
\text { mass }\end{array}$ & $\begin{array}{l}\text { Power-to- } \\
\text { Gas;Power-to- } \\
\text { Liquids;Other } \\
\text { chemicals }\end{array}$ & $\begin{array}{l}\mathrm{CO}_{2} \text { emissions } \\
\text { from energy and } \\
\text { processes; } \\
\text { Production costs }\end{array}$ & $\begin{array}{l}\text { In order to ensure the climate benefit of Power-to-X } \\
\text { solutions, the authors only consider a non-fossil } \\
\text { origin for } \mathrm{CO}_{2} \text {, but the model also considers } \mathrm{CO}_{2} \\
\text { capture for the power sector. Additionally, } \\
\text { dihydrogen molecules feeding these processes come } \\
\text { from carbon-neutral electricity. Synthetic fuels are } \\
\text { available only for road transport and compete with at } \\
\text { least } 8 \text { other fuel types, which restricts the potential } \\
\text { PtX roll-out. }\end{array}$ \\
\hline $\begin{array}{l}\text { (Siskos et al., } \\
\text { 2015) }\end{array}$ & $\begin{array}{l}\text { A technology-rich model running over } \\
\text { endogenous demand is utilized to } \\
\text { propose a decarbonization strategy solely } \\
\text { for the European transport sector, in } \\
\text { which Power-to-X solutions are made } \\
\text { available within the model. }\end{array}$ & $\begin{array}{l}\text { PRIMES- } \\
\text { TREMOVE }\end{array}$ & $\begin{array}{l}\text { Energy } \\
\text { system }\end{array}$ & Hybrid & Europe & 2050 & Decarbonization & $\begin{array}{l}\text { DAC;Pow } \\
\text { er } \\
\text { sector;Ind } \\
\text { ustry;Bio } \\
\text { mass }\end{array}$ & $\begin{array}{l}\text { Power-to- } \\
\text { Gas;Power-to- } \\
\text { Liquids;Other } \\
\text { chemicals }\end{array}$ & $\begin{array}{l}\mathrm{CES} \text { functions; } \\
\mathrm{CO}_{2} \text { emissions } \\
\text { from energy and } \\
\text { processes; } \\
\text { Production costs }\end{array}$ & $\begin{array}{l}\text { The PRIMES-TREMOVE model is an extension of } \\
\text { the PRIMES model devised to genereate endogenous } \\
\text { energy demand profiles. The modeling is thus } \\
\text { composed of two dynamic steps 1) a technology } \\
\text { choice module determinining the vehichelecthologies } \\
\text { with their related fuels as a result of a discrete } \\
\text { problem based on technology costs 2) a transport } \\
\text { demand module simulating the demand for transport } \\
\text { considering the transport activity and the maximized } \\
\text { passenger utility. CES functions are utilized to } \\
\text { describe the technologies and fuel choices of } \\
\text { consumers. }\end{array}$ \\
\hline (Takeshita, 2013) & $\begin{array}{l}\text { Global assessment of } \mathrm{CO}_{2} \text { capture and } \\
\text { storage in a cost-optimal fashion. The } \\
\text { authors include one technology to } \\
\text { convert pure } \mathrm{CO}_{2} \text { into methanol for } \\
\text { industrial thermal demand. }\end{array}$ & $\begin{array}{l}\text { REDGEM70 } \\
\end{array}$ & $\begin{array}{l}\text { Energy } \\
\text { system }\end{array}$ & $\mathrm{BU}$ & World & 2050 & $\begin{array}{l}50 \% \text { cut in } \mathrm{CO}_{2} \\
\text { emissions } \\
\text { compared to } \\
2005 \text { level }\end{array}$ & $\begin{array}{l}\text { Power } \\
\text { plants;Bio } \\
\text { mass;Fisc } \\
\text { her- } \\
\text { Tropsch } \\
\text { process }\end{array}$ & Methanol & $\begin{array}{l}\text { Techno- } \\
\text { economic } \\
\text { attributes; } \\
\text { Emissions } \\
\text { reductions }\end{array}$ & $\begin{array}{l}\text { The authors perform a cost-optimal scenario with } \\
\text { price-induced energy demand reductions and fuel } \\
\text { switching, notably. } \mathrm{CO}_{2} \text { utilization is not at the core } \\
\text { of the study but is part of a arch description of the } \\
\text { supply chain in a bottom-up fashion, enabling sector } \\
\text { coupling studies. }\end{array}$ \\
\hline $\begin{array}{l}\text { (Quarton and } \\
\text { Samsatli, 2020) }\end{array}$ & $\begin{array}{l}\text { In the context of growing interest in CCS } \\
\text { and CCU technologies, the authors take } \\
\text { into consideration this set of technologies } \\
\text { to decarbonize the British energy system. }\end{array}$ & $\begin{array}{l}\text { Value Web } \\
\text { Model }\end{array}$ & $\begin{array}{l}\text { Energy } \\
\text { system }\end{array}$ & $\mathrm{BU}$ & UK & 2050 & $\begin{array}{l}\text { Decarbonization } \\
\text { target }\end{array}$ & $\begin{array}{l}\text { Power } \\
\text { plants;Hy } \\
\text { drogen }\end{array}$ & Methanol & $\begin{array}{l}\text { Techno- } \\
\text { economic } \\
\text { parameters; } \\
\text { Demands; } \\
\text { Existing } \\
\text { capacities; }\end{array}$ & $\begin{array}{l}\text { The authors provide a transparent mathematical } \\
\text { description of the model formulation for } \mathrm{C}_{2} \\
\text { utilization technologies with the total rate of } \mathrm{CO}_{2} \\
\text { production from industrial emissions, economic } \\
\text { penalties, and rewards for } \mathrm{CCUS} \text { processes. } \\
\text { Economic incentives for } \mathrm{CCUS} \text { are modeled, i.e., } \\
\mathrm{CO}_{2} \text { pricing and variation of methanol market price. }\end{array}$ \\
\hline
\end{tabular}




\begin{tabular}{|c|c|c|c|c|c|c|c|c|c|c|c|}
\hline $\begin{array}{l}\text { (Cunha et al., } \\
2020 \text { ) }\end{array}$ & $\begin{array}{l}\text { No particular study on } \mathrm{CO}_{2} \text { utilization } \\
\text { has been performed with this model, to } \\
\text { our knowledge. But the model still } \\
\text { represents EOR as an option to produce } \\
\text { liquid fuels. }\end{array}$ & $\begin{array}{l}\text { COFFEA- } \\
\text { TEA }\end{array}$ & $\begin{array}{l}\text { Energy } \\
\text { system }\end{array}$ & TD & World & 2100 & N/A & $\begin{array}{l}\text { Power } \\
\text { plants;Hy } \\
\text { drogen;IIn } \\
\text { dustry }\end{array}$ & EOR & $\begin{array}{l}\text { Carbon storage } \\
\text { coefficient; } \mathrm{CO}_{2} \\
\text { injection rate } \\
\text { per barrel; } \\
\text { Production costs }\end{array}$ & $\begin{array}{l}\text { The model makes a distinction between EOR storage } \\
\text { fields and saline aquifers. The potential for } \mathrm{CO} 2 \\
\text { storage is calculated from the amount of oil that can } \\
\text { be recovered with } \mathrm{CO}_{2} \text { injection, considering a } \\
\text { coefficient varying between } 0.27 \text { and } 0.32 \mathrm{tCO}_{2} \text { per } \\
\text { barrel. }\end{array}$ \\
\hline $\begin{array}{l}\text { (Zhang et al., } \\
\text { 2020) }\end{array}$ & $\begin{array}{l}\text { In order to deploy CCUS or mitigate } \mathrm{CO}_{2} \\
\text { emissions, the authors design the best } \\
\text { utilization framework. The models are } \\
\text { solved both by cost minimizing and } \\
\text { emission minimizing. }\end{array}$ & No name & Supply Chain & $\mathrm{BU}$ & $\begin{array}{l}\text { North- } \\
\text { East } \\
\text { China }\end{array}$ & Not stated & $\begin{array}{l}70 \mathrm{MtCO}_{2} / \mathrm{yr} \\
\text { emissions } \\
\text { reduction }\end{array}$ & $\begin{array}{l}\text { Power } \\
\text { plants;Ind } \\
\text { ustry;Bio } \\
\text { mass }\end{array}$ & EOR & 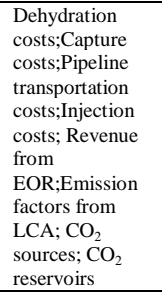 & $\begin{array}{l}\text { Very detailed mathematical assumptions are } \\
\text { provided regarding the } \mathrm{CO}_{2} \text { sources to be selected } \\
\text { for capture, the pattern for } \mathrm{CO}_{2} \text { pipeline } \\
\text { transportation, } \mathrm{CO}_{2} \text { capture technology, utilization } \\
\text { and storage nodes, and optimal cost-based } \\
\text { deployment strategy of CCUS supply chains. }\end{array}$ \\
\hline
\end{tabular}


Simply registering the number of occurrences for a specific utilization process, we notice that $\mathrm{CO}_{2}$-tofuels processes stand out from the crowd (Figure 1), followed by $\mathrm{CO}_{2}$-to-chemicals processes. " $\mathrm{CO}_{2}$ to-fuels" is a generic term to qualify technologies that process $\mathrm{CO}_{2}$ and $\mathrm{H}_{2}$ to manufacture either liquid (PtL) or gaseous (PtG) fuels ultimately meant to be burned. Sometimes, the term PtG is used to define the conversion of renewable electricity into hydrogen through electrolysis. Here, PtG refers solely to the manufacture of synthetic natural gas or methane. When hydrogen features as an output of $\mathrm{CO}_{2}$ utilization in Figure 1, this means that the authors are considering the dry reforming of methane (Carapellucci and Giordano, 2020). PtL includes diesel, gasoline, and jet fuels.

In Figure 1, the "chemicals" label comprises methanol (which can both be considered as a fuel and a feedstock for the chemical industry), along with olefins, formic acid, ethanol, dimethyl carbonate, acetic acid, and ethylene carbonate. Urea is a particular product that is often represented in integrated assessment models because it is currently the largest consumer of $\mathrm{CO}_{2}$ and its production is expected to continue because of population growth. Thus, due to its current status, $\mathrm{CO}_{2}$-to-fertilizers needs to be represented in models to better represent the potential of $\mathrm{CO}_{2}$ capture. However, this utilization does not constitute an option for $\mathrm{CO}_{2}$ emissions mitigation, unless biogenic or atmospheric $\mathrm{CO}_{2}$ is used. Contrary to fuels, chemicals, and fertilizers, much less attention is paid to building materials, plastics and biomass growing despite the fact that these $\mathrm{CO}_{2}$ uses will certainly bind $\mathrm{CO}_{2}$ for longer periods, thus having a positive impact on the climate.

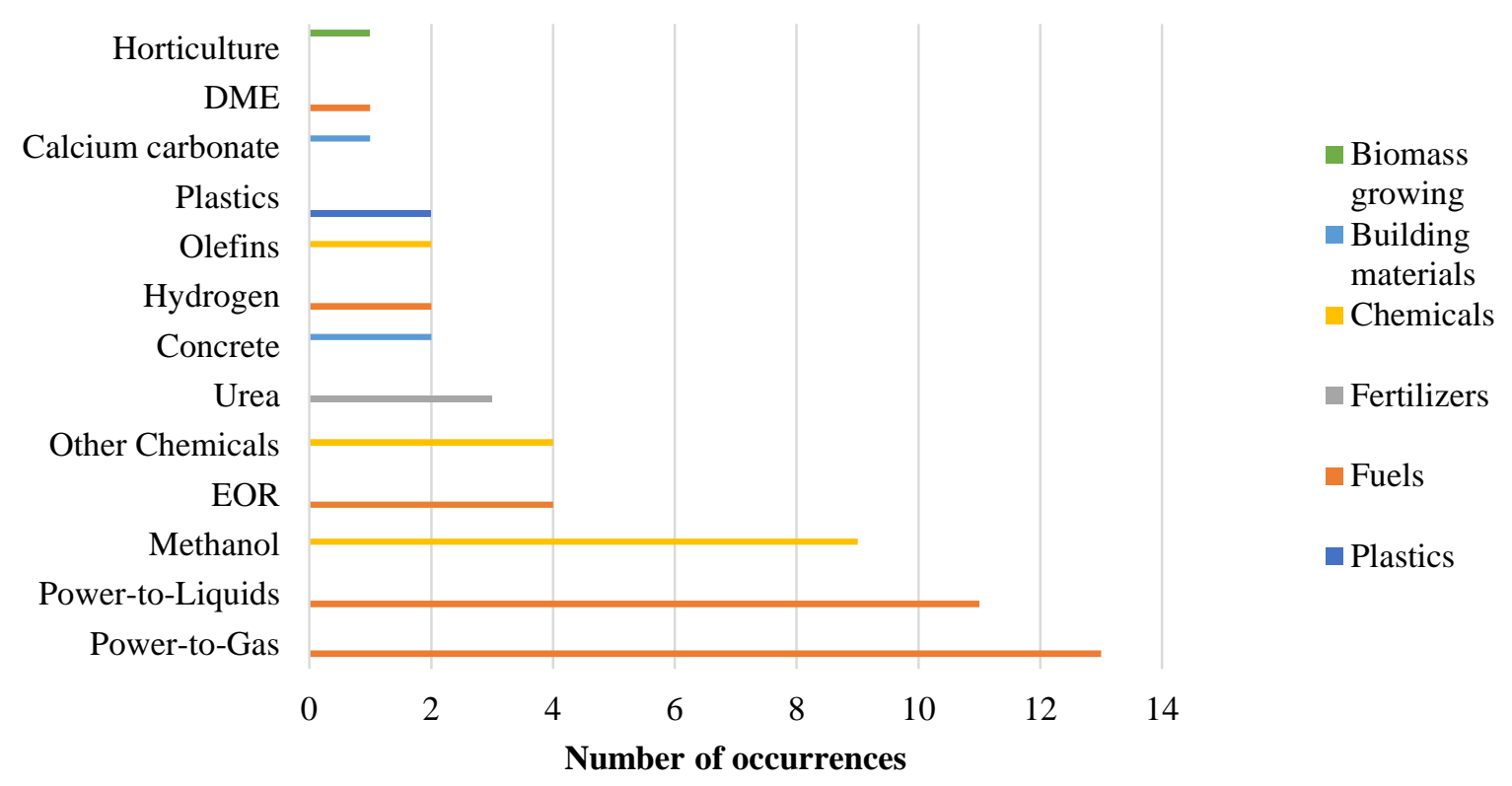

Figure 1: Occurrences of specific $\mathrm{CO}_{2}$ utilization bricks over the 22 models reviewed

Energy models tend to focus on the potential of only one $\mathrm{CO}_{2}$-to-X option. Energy models that include various CCU options (Bazzanella and Ausfelder, 2017; Leonzio et al., 2020) are rarely performed. Consequently, it is currently difficult to envision the real potential of $\mathrm{CO}_{2}$ utilization in the future through energy models. Other studies that do not employ energy models still identify $\mathrm{CO}_{2}$-tofuels and $\mathrm{CO}_{2}$-to-chemicals as the most interesting options in the $\mathrm{CO}_{2}$ utilization package (Armstrong and Styring, 2015; “CO $\mathrm{CO}_{2}$ Utilization,” 2017; Gabrielli et al., 2020; Hepburn et al., 2019; ICEF, 2016). Thus, the domination of $\mathrm{CO}_{2}$-to-fuels and $\mathrm{CO}_{2}$-to-chemicals representation in energy models is in line with the expectations of studies of a different kind. This also corresponds to the funding attributed to $\mathrm{CO}_{2}$ utilization in R\&D (Kapetaki et al., 2019) in favor of $\mathrm{CO}_{2}$-to-fuels and $\mathrm{CO}_{2}$-to-chemicals. 


\section{How $\mathrm{CO}_{2}$ utilization technologies are represented in energy models}

Since the place of CCU in the results of energy models is highly dependent on how it is modeled, we review the assumptions and methods of the models in the present section. As indicated in the fourth column of Table 1, two types of model can be differentiated. On the one hand, Energy System Models (ESMs) focus on modeling the energy system by considering several options for decarbonization. Therefore, CCU is just one of the options available to ESMs to mitigate climate change and these models need to represent different value chains to capture the competition between each other and deliver a realistic assessment of future needs. Thus, in the chemical sector, one study for example considered biomass energy and renewables in addition to the use of $\mathrm{CO}_{2}$ in order to better capture both interactions and competition between them (Bazzanella and Ausfelder, 2017). In the transport sector, Blanco et al. (2018a) also took into account biofuels, electricity, and hydrogen. This kind of model is useful to evaluate the change in energy production assets considering several value chains in terms of their potential and contribution to reach a climate target. On the other hand, Value Chain Models (VCMs) focus on the specific chain of CCU - or CCUS - from the capture site to the utilization site, comprising transport and the many other processes involved. This ensures a detailed and comprehensive representation of CCU and may capture information that ESMs cannot grasp in terms of technology feasibility and details (Fasihi et al., 2019) as well as geographical constraints and technology insertion into the geographic scope of the current energy system (Leonzio et al., 2020, 2019; Leonzio and Zondervan, 2020; Zhang et al., 2020). Generally, the purpose of VCMs is to design optimal supply chains of carbon in order to satisfy an industrial demand under the climate constraint. They can determine and quantify the least costly $\mathrm{CO}_{2}$ emission point sources, capture technologies, transportation design, and fate of $\mathrm{CO}_{2}$ (whether storage or utilization).

Thus the main difference between ESMs and VCMs lies in the level of aggregation of a technology. Generally, ESMs are utilized in prospective studies attempting to forecast a sustainable path to reach energy system decarbonation. Consequently, these models are time dynamic, i.e. they solve multiperiod problems based on optimized solutions, and need to parametrize CCU mainly with technoeconomic and environmental performances (see the last two columns of Table 1). Contrarily, VCMs do not usually deliver results over time, but propose a new static way of including CCU in the current energy mix to mitigate a determined quantity of carbon. They often need to parametrize their modeling with geographical data on the location of capture, utilization and storage sites. From our overview, 15 ESMs integrate the use of $\mathrm{CO}_{2}$ as a lever to reach a climate target, in competition with other alternatives such as hydrogen, biomass and electrification (Table 1). The remaining 7 models are VCMs.

To be more specific, the ESM family includes two members, namely bottom-up (BU) and top-down models (TD), that are distinguished by the way they integrate and represent the energy sector (Figure 2). Table 1 indicates in the fifth column whether the model is BU or TD. 


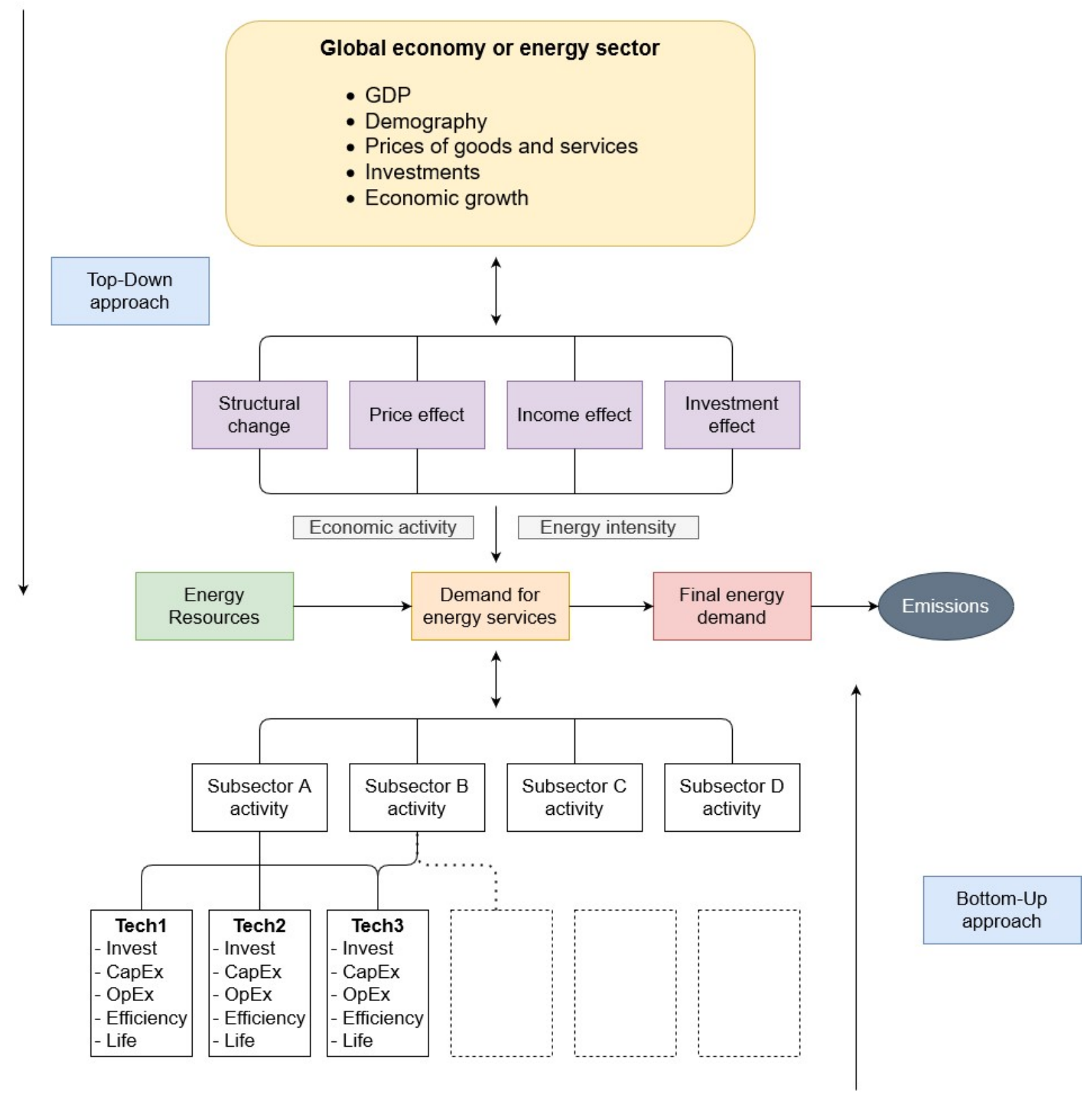

Figure 2: Diagram of bottom-up and top-down approaches inspired by (Assoumou, 2006)

BU models are characterized by their high level of technological detail (Assoumou et al., 2018; Subramanian et al., 2020). The models' rich representation of the energy system enables the modelers to describe any process in a complete way, including energy, material and pollutant flows, and the economic and financial properties related to an investment, including capital costs, operation costs, lifetime, discount rate, etc. (Sathaye and Sanstad, 2004). These data are most often extracted from existing techno-economic studies (Algehed et al., 2009), which explains the high diversity of inputs from one model to another. Such a need for an extensive database constitutes a major drawback for BU models (Subramanian et al., 2020). Figure 3 gives a generic example of what a CCU supply chain resembles in BU models, as one can find in the BU references in Table 1.

BU models mainly try to determine an optimal framework that minimizes the total annual cost of fulfilling energy demand or maximizing energy efficiency by selecting the appropriate technologies under several constraints, e.g. potentials and availability of resources, carbon tax, or GHG emissions limited to an upper bound. The results vary from one model to another depending on the level of 
temporal, spatial, technical and economic detail, as well as their ability to consider sector coupling (Prina et al., 2020). They are mainly addressed at industrial and non-industrial policymakers in search of robust strategic planning of energy generation in respect of climate goals. Nevertheless, BU models are criticized for providing results with poor behavioral and economic realism (Hourcade et al., 2006). Since they only model the evolution of an energy system over time, they are unable to assess the future demand for energy services across sectors, which is highly dependent on interactions with the rest of the economy. Therefore, these models need to be fed with exogenous energy demand forecasts (Helgesen, 2013) which can be imported from TD models (Loulou and Labriet, 2008). TIMES models are good examples of BU models (ETSAP, 2021) (Table 1).

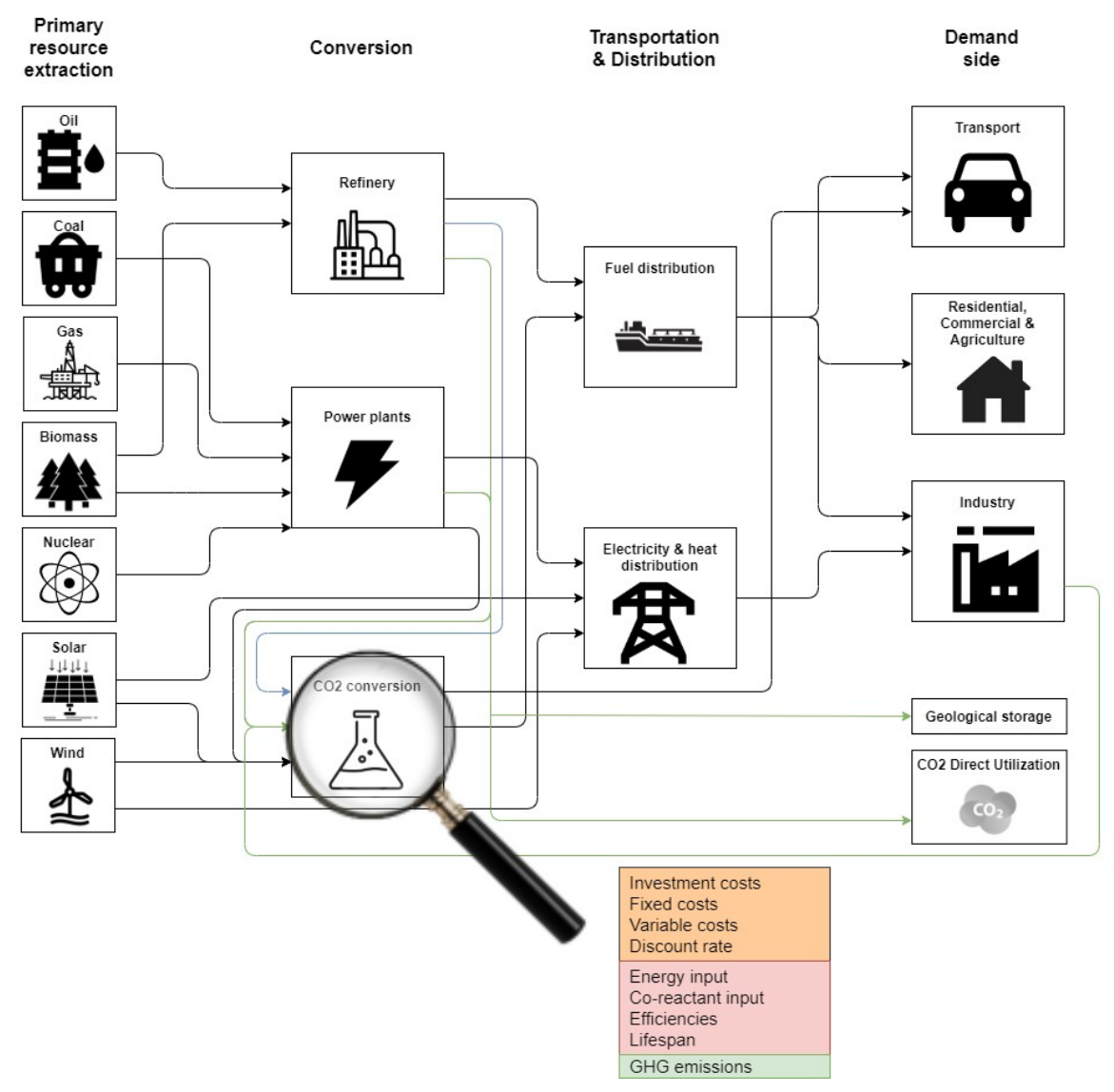

Figure 3: CCU generic modeling under BU frame inspired by (Subramanian et al., 2020)

One characteristic of BU models is that they consider a large array of techno-economic properties and constraints for any technology bricks or processes, which are here embodied in the rectangles and squares. These include pure economic ones (orange box), technical ones (red box) and environmental ones (green box)

Indeed, TD models are based on the interactions between the energy system and the rest of the economy, notably through econometric techniques and Computable General Equilibrium (CGE), since they model all sectors of the economy. They are known to give a broad representation of the entire economy at the expense of low technology explicitness (Assoumou et al., 2018), i.e. available technologies are often aggregated into technology packages with few details on how the process works and neglecting sector coupling (Prina et al., 2020). Typically, the coal power sector is embodied in one process, whilst BU models feature different processes for coal power generation, including supercritical pulverized coal, atmospheric fluidized bed, and others. However, their strength is that they can capture feedback from markets by representing primary production factors and consumption of goods considering prices, incomes, and savings. Thus, TD models perform a general equilibrium of the entire economy while BU models perform a partial equilibrium of the energy sector. One branch of TD models is called CGE, which operate on the basis of microeconomics (Assoumou et al., 2018; Hourcade et al., 2006) through social accounting matrixes, elasticities of 
various kinds and Constant Elasticities of Substitution (CES) functions (Algehed et al., 2009). Governments and economists utilize this family of models to assess the impact of an energy policy on the rest of the economy. Figure 4 shows a generic simplified diagram of how $\mathrm{CO}_{2}$ utilization can be incorporated into a CGE model.

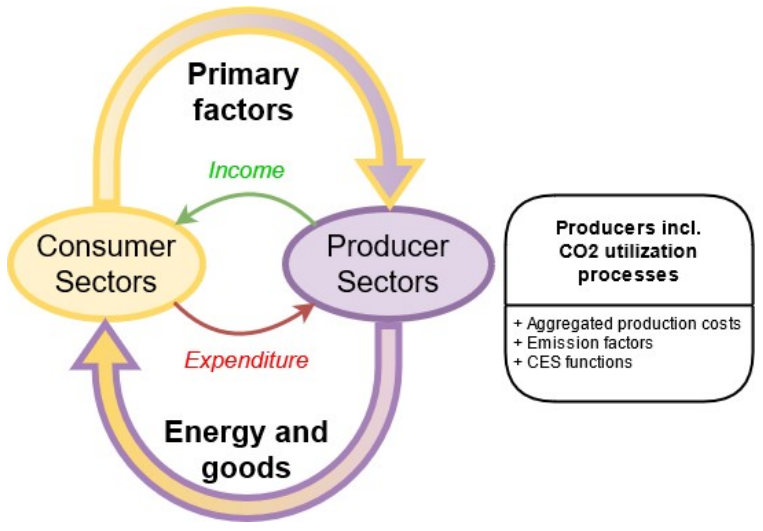

Figure 4: CCU generic modeling in TD models

In TD models, techno-economic properties of the processes composing the energy sector or the producer sector are not diverse but mostly aggregated and require other information such as CES functions (represented in the side box). In exchange, TD models focus better on modeling the economic feedback that consumers return to producers (represented by the top arrow)

Behind the CES functions of CGE models are price elasticities and elasticities of substitution that reflect the preferences and willingness of consumers to switch from one way of consuming to another (Chen et al., 2017, p. 5; Rutherford, 2009). These elasticities are nested to form a cost function with multi-level nodes representative of the consumer's behavior for a utility. For instance, synfuels can be included in a CGE model as in Figure 5 with the PRIMES-TREMOVE model (Capros and Siskos, 2011). In this decision tree representing small cars, the consumer faces a first choice between a vehicle running on gasoline, diesel, pure electric or hydrogen, then a second choice for the refueling type, and a last choice for a fuel input whose carbon content is dependent on European norms (ACEA, 2021). Thus, if production costs and prices relative to synfuels are implemented upstream, we might imagine alternative $\mathrm{CO}_{2}$-based fuels to be included in one of the European classifications.

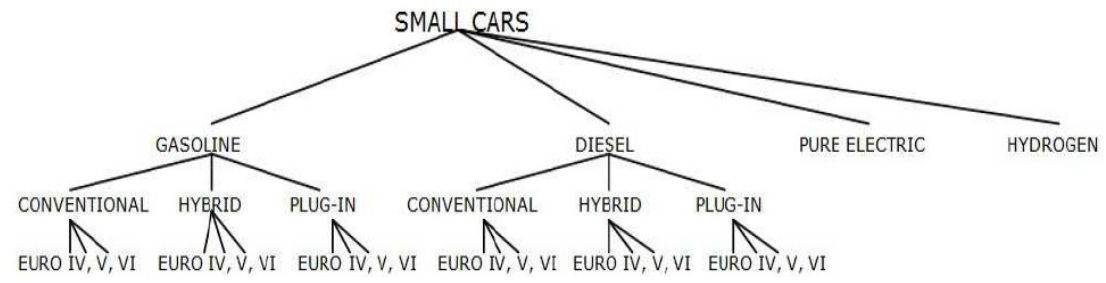

Figure 5: CES function for small cars in the PRIMES-TREMOVE model (Capros and Siskos, 2011)

Thus, ESM can either be classified as BU or TD, depending on the aggregation level of the technology.

Some models combine both BU and TD characteristics and are classified as hybrid (Helgesen, 2013; Hourcade et al., 2006). As Table 1 shows, we note a clear domination of BU models in the modeling of $\mathrm{CO}_{2}$ utilization. This may be symptomatic of the lack of socio-economic data related to CCU that TD models require.

Nevertheless, important data about the techno-economic and environmental performances of $\mathrm{CO}_{2}$ utilization processes can be found in the references of Table 1. This information determines input commodities (e.g., electricity, hydrogen and $\mathrm{CO}_{2}$ ) to deliver output commodities (e.g. synfuel, chemicals, etc.) considering a specific CapEx, OpEx and efficiency (Figure 3). The origin of $\mathrm{CO}_{2}$ is of 
great interest because it reflects the purpose of $\mathrm{CO}_{2}$ utilization and leads to a more comprehensive analysis of the contribution of CCU in decarbonizing energy systems:

- If the $\mathrm{CO}_{2}$ is biosourced or captured from the atmosphere, then the processes transforming or directly utilizing $\mathrm{CO}_{2}$ can generate negative emissions or carbon-neutral products, depending on the $\mathrm{CO}_{2}$-based product generated. The previous statement is true in theory, but in practice biomass management and DAC can generate emissions at many levels of the CCU chain, which would make the overall CCU process a net emitter (Cuéllar-Franca et al., 2019);

- If the $\mathrm{CO}_{2}$ comes from industrial emissions, then $\mathrm{CO}_{2}$ utilization processes can leverage the cost of capturing unavoidable $\mathrm{CO}_{2}$ from the industry by adding value to it, rather than storing it more expensively.

- If $\mathrm{CO}_{2}$ is emitted due to the combustion of fossil resources and treated afterwards, this can be helpful to guarantee a degree of flexibility on the electricity network. Energy-related $\mathrm{CO}_{2}$ is cheaper to capture than to process, and cheaper than biogenic $\mathrm{CO}_{2}$, so it can be an opportunity to run $\mathrm{CO}_{2}$ utilization processes at the lowest cost.

As Figure 6 shows, biogenic and atmospheric $\mathrm{CO}_{2}$ utilization are of great interest concerning the production of $\mathrm{CO}_{2}$-based products or the direct utilization of $\mathrm{CO}_{2}$. Indeed, treating biogenic $\mathrm{CO}_{2}$ is essential to ensure that $\mathrm{CO}_{2}$ utilization processes have a beneficial or neutral impact on climate due to the short lifespan of $\mathrm{CO}_{2}$-based products. As most of the studies discuss the contribution of synfuels in climate mitigation (Figure 1), modeling climate neutral $\mathrm{CO}_{2}$ capture is a milestone and explains why so many of them feature DAC and bioenergy with carbon capture processes. In some studies, in fact, biogenic $\mathrm{CO}_{2}$ is the only available option for $\mathrm{CO}_{2}$ utilization processes (Bogdanov et al., 2019; Fasihi et al., 2017), and is not subject to the carbon tax (IEA, 2019c). Carbon capture for the hydrogen industry does not seem to be of interest in CCU modeling, although it is one of the cheapest options for carbon capture processes (Leeson et al., 2017). In the power sector, carbon capture is generally modeled because it is a common mean to decarbonize power generation, and consequently electrolysis. The literature on techno-economic assessments of carbon capture processes has been very prolific in recent years, so that it is now commonly present in models, with different levels of detail: $\mathrm{BU}$ models can consider diverse post-combustion $\mathrm{CO}_{2}$ reactants (e.g. MEA, PZ, membranes, etc.) and include pre-combustion and oxycombustion capture techniques as well. Their modeling is not necessarily designed to feed $\mathrm{CO}_{2}$ utilization facilities, but rather to generate negative emissions through BECCS, or simply to help decarbonize electricity generation.

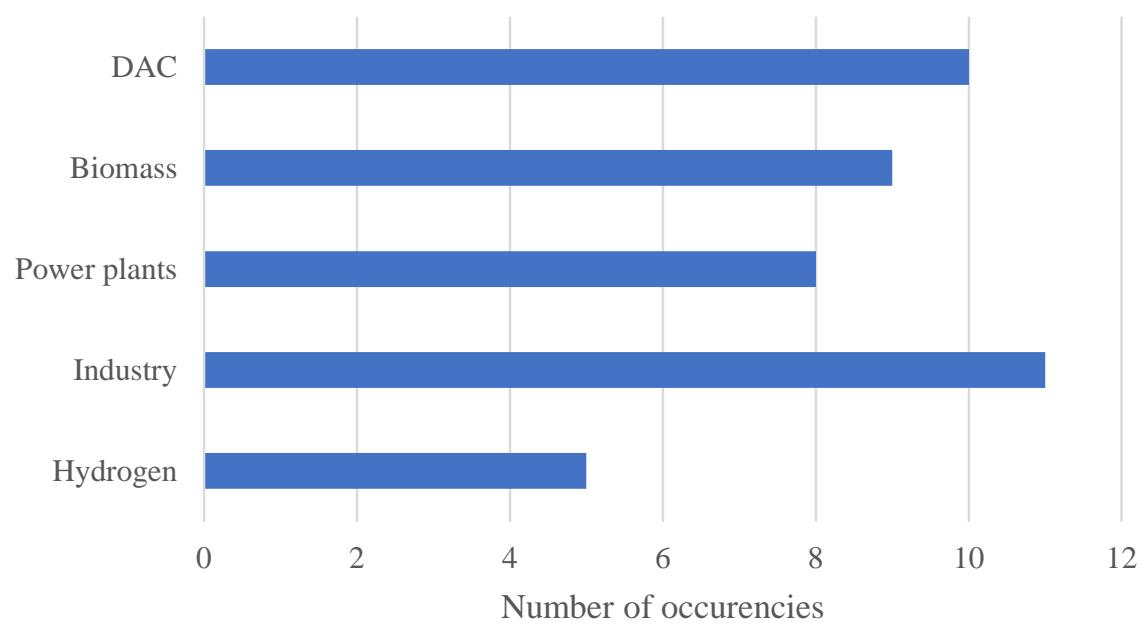


Thus, depending on the model, $\mathrm{CO}_{2}$ capture is found at different levels of the energy system.

However, we note that modeling capture at all levels is a rare but crucial practice to fully integrate the CCU chain in the models, and thus better assess its potential.

\section{Discussion, recommendations, and drivers of CCU}

\subsection{Barriers to including CCU in energy models}

The previous sections have highlighted that, according to the set of models reviewed, the modeling of CCU suffers from four major flaws, namely: a lack of integration for capture processes; a lack of consideration of the various utilization routes notably for the industry sector; a lack of modeling at the global level; and a lack of modeling in TD models. We can see an obvious reason why CCU is poorly modeled, and that is the lack of data. The past five years have been quite prolific with regard to the number of TEA and LCA studies about the conversion of $\mathrm{CO}_{2}$ into fuels and chemicals (Marchese et al., 2021), but other options for utilizing $\mathrm{CO}_{2}$ tend to be neglected. As a matter of fact, the TEAs and LCAs reveal that the major techno-economic barriers that CCU faces are low TRL (Chauvy et al., 2019), low development potential (Ampelli et al., 2015), high costs of $\mathrm{CO}_{2}$ capture (Fuss et al., 2018; Irlam, 2017; Leeson et al., 2017), and limited climate benefits (Ravikumar et al., 2021).

The number and importance of these barriers may discourage modelers from implementing the CCU option within their models. At least these barriers have the benefit of being quantitative and easy to model, but other hard-to-model barriers related to energy markets and the economy work against the integration of CCU in energy models. Indeed, the current demand for $\mathrm{CO}_{2}$-based products (mainly fertilizers at the moment) is still low (Kapetaki et al., 2019, sec. 5.3.2) and not expected to grow substantially unless synfuels emerge and benefit from their high substitutability with current products. However, $\mathrm{CO}_{2}$-based products are currently too expensive compared to conventional processes and cost-competitiveness is an acknowledged key challenge to be addressed. To date, EOR is the only $\mathrm{CO}_{2}$ utilization process that can compete with conventional processes (Hepburn et al., 2019), thus stakeholders have no interest in investing in other CCU options for now. Competition also occurs between other equally useful low-carbon options for decarbonizing the various sectors of an energy system. In general, energy models choose the cheapest technology to satisfy energy demand as they usually perform a cost minimization. Given the wide pallet of possibilities, CCU options are thus not likely to rank high in the merit order. Finally, chemical and fuel markets are difficult to penetrate because they are already saturated, capital-intensive and highly competitive (de Pee et al., 2018). As a result, we find it difficult to imagine new players entering the market with products manufactured via CCU. It is much more likely that incumbent stakeholders would retrofit their existing assets with CCU. This requires that energy models consider existing agents separately from potential new agents in their representations, which is not a common feature of such models.

Thus, we assume that CCU suffers from a lack of consideration in energy models because of the many aforementioned hurdles. In addition to these obstacles, it is essential to state that CCU might not be beneficial to the climate issue, notably because most $\mathrm{CO}_{2}$-based products cannot retain carbon for long periods of time. As we highlighted in the previous section, $\mathrm{CO}_{2}$ utilization processes running on non-fossil $\mathrm{CO}_{2}$ (i.e. atmospheric or biogenic) would likely be favored in the future as they can be carbon negative or carbon neutral, in theory. In reality, producing concentrated climate-neutral $\mathrm{CO}_{2}$ is currently expensive and technically difficult to achieve because it relies on many processes which themselves emit $\mathrm{CO}_{2}$. Taking the example of biogenic $\mathrm{CO}_{2}$, we see that forest management, transport of biomass feedstock, the biomass feedstock process, and capture of $\mathrm{CO}_{2}$ can, in the end, be detrimental to the overall CCU process and make it a net $\mathrm{CO}_{2}$ emitter. Additionally, the period of time during which the forest regrowth reabsorbs atmospheric $\mathrm{CO}_{2}$ emissions far exceeds the $\mathrm{CO}_{2}$ emissions from biomass combustion, thus having the opposite effect of what is called 'renewable energy' - this is mainly true for woody biomass and less so for energy crops. Hence, biomass carbon neutrality, as 
generally assumed in models and calculations, has increasingly been demonstrated as incorrect and misleading (Norton et al., 2019; Slade et al., 2018). Consequently, caution should be exercised when modeling biogenic $\mathrm{CO}_{2}$.

In the face all of these barriers and uncertainties, there are apparently good reasons not to consider CCU in energy models. However, interest in CCU modeling should not stop with these seemingly unfavorable characteristics because they can be consolidated or refuted by energy models. Moreover, both industrialists and individuals are much more interested in CCU than in CCS, with regard to the number of global CCUS projects (IOGP, 2021), because the former generates revenues while the latter only involves costs if the carbon prices rise enough . Regarding industrialists' interest in CCU, energy models could be used, not to estimate CCU potentials, but to assess the climate impacts of CCU if stakeholders commit to developing this technology. Thereby, we strongly call for the modeling of CCU.

\subsection{Drivers of CCU in energy models}

Interestingly, the aforementioned barriers can be mitigated or counterbalanced with other measures or breakthroughs to be implemented in energy models. Because of the many interactions that link $\mathrm{CO}_{2}$ capture and utilization to the rest of the energy system, there are several parameters adjacent to CCU that are nevertheless part of its modeling and that can influence the results of energy models, namely the hydrogen sector, the electricity sector, and various demand sectors.

Firstly, low-carbon electricity is both a competitor and a promoting agent for $\mathrm{CO}_{2}$ utilization because a large part of $\mathrm{CO}_{2}$-based products can be manufactured through electrochemical conversion processes that are cost-driven by electricity. Feeding CCU processes with dedicated low-carbon electricity generation is thus a lever that would ensure the implementation of processes to avoid $\mathrm{CO}_{2}$ emissions rather than conventional processes. It would attract a great deal of interest if this lowcarbon electricity were generated at costs lower than 50 USD/MWh (de Pee et al., 2018). Likewise, hydrogen is both a competitor and co-reactant of most $\mathrm{CO}_{2}$ utilization processes. As a result, clean, cheap production of hydrogen is an important milestone for CCU deployment. To illustrate the importance of this lever, one study explored the potential of $\mathrm{CO}_{2}$-based products when the availability of renewable hydrogen varies and confirmed that the potential for $\mathrm{CO}_{2}$-to-fuels is way greater when renewable $\mathrm{H}_{2}$ is an unlimited resource (Dutta et al., 2017). Besides, the roll-out of $\mathrm{CO}_{2}$ utilization is highly dependent on the decreased cost of hydrogen production in the future, and the literature features some very diverging assumptions regarding future trends (IRENA, 2020; Schmidt et al., 2017). It is up to modelers to make more or less strong assumptions on the evolution of costs for both low-carbon electricity and hydrogen over time. The decrease in costs can be justified by assuming the future scaling of processes as well as research funding for more efficient $\mathrm{CO}_{2}$ utilization processes (Cuéllar-Franca et al., 2019). As for many novel technologies, process scaling is a well-known lever to improve the efficiency of processes and reduce costs (Kim, 2021; Mauler et al., 2021; Yoshida et al., 2021). This strategy is also recommended for CCU (Cuéllar-Franca et al., 2019; Luna et al., 2019). We argue that such assumptions should be formulated and justified in the context of specific modeling scenarios in which either high or low performances for hydrogen and electricity are assumed. Secondly, we point out the importance of building so-called " $\mathrm{CO}_{2}$ hubs", which consist in concentrating the industries requiring $\mathrm{CO}_{2}$ as feedstock with other $\mathrm{CO}_{2}$-emitting industries equipped with $\mathrm{CO}_{2}$ capture units within a nested web. The concept involves creating synergies between capture units, renewable energy generation and smart grids (Sandalow et al., 2019), in order to improve the overall efficiency and reduce the costs of the infrastructure web, notably for $\mathrm{CO}_{2}$ transportation (Bui et al., 2018; IEA, 2019c). This consideration could steer CCU in energy models and will in any case need to be modeled, as such hubs are currently in development in Europe (IOGP, 2019). 
Over and above technical levers, the development of CCU in energy models could also benefit from policies. As a matter of fact, Table 1 shows that energy models provide poor information about climate policies in favor of developing $\mathrm{CO}_{2}$ utilization. Indeed, except for some models that consider a carbon tax (Leonzio et al., 2019; Quarton and Samsatli, 2020), or others studying the impact on $\mathrm{CO}_{2}$ storage unavailability (Blanco et al., 2018a; IEA, 2019b), the modeling of $\mathrm{CO}_{2}$ utilization is not addressed within a specific climate policy, unlike incentives for renewable technologies or a planned deployment rate. (Keppo et al., 2021) acknowledge that policies other than carbon pricing are usually not present in all IAMs, especially local or sector-specific ones, hence biasing the outcome of the models. The following list enumerates three main policy levers that would drive $\mathrm{CO}_{2}$ utilization deployment in the results of energy models.

\section{1. $\mathrm{CO}_{2}$ pricing or carbon taxation}

A major policy lever is the implementation of a carbon tax that would attribute a value to $\mathrm{CO}_{2}$ emissions of $\$ 40-\$ 80 / \mathrm{tCO}_{2}$. Henceforth, a major issue arises: how do we measure $\mathrm{CO}_{2}$ emissions reduction when the sequestration of $\mathrm{CO}_{2}$ in a product is not permanent, and how do we account for negative emissions? Because each CCU route may have different environmental benefits, we argue that a $\mathrm{CO}_{2}$ price should be indexed for each $\mathrm{CO}_{2}$-based product depending on its climate benefit, indicating once more the need for robust LCAs. This issue still needs to be addressed by modelers.

\section{Policy incentives}

Policy incentives can take various forms, such as tax credits, product labelling, R\&D funding or direct government funding for projects (ICEF, 2016). In this area, we observe that it is very simple in energy modeling to incentivize the production of $\mathrm{CO}_{2}$-based goods with subsidies by lowering the investment cost (CapEx) in CCU assets, or by lowering the production cost to a certain level. It remains for modelers to decide on the magnitude of these incentives, for example by working with sensitivity analyses. However, researchers warn not to incentivize CCU projects unless a robust life-cycle assessment of emissions savings has been performed upstream (Hepburn et al., 2019; IEA, 2020).

3. Legal and policy framework

Finally, a policy framework, as well as a legal framework, should be built globally (Nakamura et al., 2019) to ensure fair competitiveness between actors, and to avoid regional actors being penalized by others. Although necessary for the successful development of CCU, this lever seems hard to model. However, one might imagine for a given scenario that all agents from all regions in all sectors of the energy system modeled are constrained by the same climate policies. For IAMs modeling both the climate and the world energy system, a simple way to consider a legal framework is to constrain the energy system to its related GHG emissions so that the temperature of the globe does not exceed a certain level. Similarly, one can imagine that all sectors are bound to a net-zero target. Consequently, all agents are forced to transition fairly and CCU has more chance of being revealed as a significant contributor to this goal.

Thus, modelers can draw on the technical and political parameters that emerge in real projects and incorporate them into the modeling. However, we call on modelers to be transparent about assumptions in relation to the overall CCU chain.

\subsection{Recommendations for CCU modeling}

For new modelers seeking to represent CCU in energy models as a novel alternative, we make the following recommendations.

At the first link of the $\mathrm{CCU}$ chain, $\mathrm{CO}_{2}$ capture must be represented as broadly as possible in order to identify the source of $\mathrm{CO}_{2}$ (either fossil, process-related, atmospheric, native or biogenic) and quantify 
the $\mathrm{CO}_{2}$ capture requirements. The latter is essential to fully estimate the total $\mathrm{CO}_{2}$ to be captured and the former is also important to identify the strategic $\mathrm{CO}_{2}$ point sources to capture before using it. In other words, the capture of $\mathrm{CO}_{2}$ must be modeled at every possible level of the energy system considered. In a broader sense, CCU needs to be modeled in global models to assess the full potential. Of the 22 models reviewed in the present study, we note 9 global models including CCU technologies worldwide. Given the large number of global models (more than 29) in the research community (UNFCCC, 2021), we can deduce that $\mathrm{CO}_{2}$ utilization is poorly represented at the global level. Table 1 shows that Europe is the geographical area of greatest interest for the utilization of $\mathrm{CO}_{2}$. Moreover, as mentioned in Section 1, if CCU is considered in any model or study, it is implemented as an option to decarbonize a particular sector of the economy, e.g. the chemical sector or transport, but not for all sectors. Therefore, it is currently hard to assess the complete potential of CCU across all continents and all sectors, which can be detrimental for estimating the requirements of capture units, whereas CCU is modeled to this purpose (Section 1). We thus strongly recommend the complete integration of $\mathrm{CCU}$, i.e. including all types of $\mathrm{CO}_{2}$, for all sectors and all regions of the world. Bottom-up models and specifically global TIMES models are suited for such a task because they deal with energy and material flows (Loulou and Labriet, 2008). The origin of $\mathrm{CO}_{2}$ can be identified and tracked so that modelers can easily analyze from the results the role of CCU depending on the origin of the $\mathrm{CO}_{2}$.

As the second link of the CCU chain, we note a clear interest in $\mathrm{CO}_{2}$ utilization for the transport sector and the manufacture of fuels, with regard to the overview of current models. Indeed, shifting to clean fuels and enhancing energy efficiency are crucial measures to reduce emissions from this sector and avoid having to replace the entire fleet (van Vliet et al., 2011). The power sector could also abate its $\mathrm{CO}_{2}$ emissions with renewable energies or nuclear power. However, the industry sector has no choice but to rely on $\mathrm{CO}_{2}$ capture at some point, because of the difficulty of abating its process emissions. It remains to be decided whether it is more interesting to store or to utilize the captured $\mathrm{CO}_{2}$. Heavy industries could benefit from CCU to produce clean chemicals, reduce carbon footprints of cement and concrete, and enhance steel slags to increase their sales. As industry is one of the most difficult sector to decarbonize, CCU offers a milestone to define a mitigation strategy, considering all the possible routes. We thus call upon modelers to make efforts to represent $\mathrm{CO}_{2}$ utilization as broadly as possible for the industrial sector. The challenge is even greater given that most $\mathrm{CO}_{2}$ utilization processes are exothermic (specifically in the hydrogenation of $\mathrm{CO}_{2}$ to produce fuels), meaning that the residual heat can be reused within the process of the asset or directly utilized at the capture or electrolysis unit. This strategy could be a game changer for CCU modeling. Beyond the integration of heat, an overall, gate-to-gate CCU process would benefit from several different integrations that still need to be optimized and assessed to determine the most profitable design (Cuéllar-Franca et al., 2019). The integration of $\mathrm{CO}_{2}$ utilization processes is thus crucial to model, in order to get the most out of it. In addition to modeling the implementation of brand-new, stand-alone CCU facilities, we strongly recommend modeling the retrofitting of current industrial assets which have long lifespans. Instead of abandoning existing assets with a high economic impact, retrofitting existing assets might be an opportunity for CCU technologies and should be considered. In the meantime, energy models usually only incorporate the investment in new capacities as a major decision variable, while the retrofitting of existing assets is barely considered. Therefore, we argue that modelers should also consider the retrofitting of current long-life assets, and not only investment in expensive new capacities for the industry.

Apart from the technical modeling recommendations, we argue that CCU could be modeled in other contexts, such as the sustainability of the economy or a carbon circular economy. Firstly, TEAs and LCAs currently make up much of the research about CCU performance (Cruz et al., 2021), while the socio-economics of CCU raises less interest (Centi et al., 2020). This could be one reason why TD models are underrepresented in CCU modeling: they need this kind of information in order to be run. TD models have the potential to enrich the debate with further insights on the impacts of CCU roll-out on GDP, employment, fuel prices or consumption, all of which would help to assess whether CCU is 
an interesting technology to be deployed for socio-economic and environmental concerns. Currently, the results of BU models are oriented through a prism of techno-economic feasibility and the potential environmental benefits of CCU, and are likely to be challenged by the results of TD models. Secondly, we notice that $\mathrm{CO}_{2}$ utilization has never been studied in energy models in the context of a carbon circular economy, as George Olah proposed (Olah et al., 2009). The concept is to develop an economy based on the utilization of carbon coming solely from atmospheric $\mathrm{CO}_{2}$ rather than fossil fuels to satisfy our needs for fuels and other products by converting the captured carbon with clean energies. In this paradigm, the extraction and use of fossil fuels would not be needed anymore, as the world would only rely on atmospheric $\mathrm{CO}_{2}$. Gulf countries are particularly interested in the carbon circular economy due to their high potential for solar and renewable energies, making it easier to both capture $\mathrm{CO}_{2}$ and convert it with clean energies (Al-Alawi et al., 2020; Al-Sadoun, 2019; Al-Saidi et al., 2021). However, we have not identified any study that has run an energy model including CCU in the Middle East region (Table 1). If CCU were modeled in the context of a carbon circular economy, the potential for capture and use of $\mathrm{CO}_{2}$ is likely to be much larger than it would be in the context of emissions reduction; we argue that the potential of CCU assessed in either context should be confronted and discussed. Thirdly, as mentioned in section 4.2, the modeling of $\mathrm{CO}_{2}$ hubs would be interesting for VCMs. Indeed, the entire set of VCMs we reviewed considers sparse capture sites and storage sites that require expensive $\mathrm{CO}_{2}$ pipelines to link them to each other, while the cost could be minimized with $\mathrm{CO}_{2}$ hubs. We believe that the results that VCMs obtain should be compared with cases where capture, utilization, and storage sites are concentrated into hubs.

As for policy concerns, we discussed before that a legal framework is essential to promote CCU. A first step was achieved when most countries in the world ratified the Paris Agreement in 2016. All countries must now set national targets corresponding to their engagement, and ensure social acceptability and public awareness. However, in reality, some regions of the world will transition more rapidly and earlier than others. In the case of CCU, North America, Western Europe and Eastern Asia are already showing an interest in $\mathrm{CO}_{2}$ utilization. Therefore, especially for global models, we argue that both incentives and climate policies should be addressed to these regions of the world as a priority. This would render the results more realistic.

Note that the review we performed is based on the analysis of 22 studies. We are aware that our inferences are based on a non-exhaustive overview of the literature, which may bias our argument.

\section{Conclusion}

In response to climate urgency and the formulation of more stringent climate constraints embodied by the Paris Agreement, decision makers must inevitably find new levers and develop new strategies. Carbon capture and utilization technologies are of interest for both mitigating emissions and generating revenues. In order to develop this technology, an assessment of CCU potentials and performances needs to be researched, not only through TEA and LCA studies, but also employing energy models because of their ability to integrate several facets of an overall energy system.

However, our review shows that the complete representation of CCU is absent from energy models. In particular, top-down models need to make an effort to better understand the socio-economic effects of its potential deployment. Also, in order to better quantify $\mathrm{CO}_{2}$ capture capacities, we argue that CCU needs to be modeled at all possible capture sites and for all $\mathrm{CO}_{2}$ utilization processes. Although indispensable, the modeling of $\mathrm{CO}_{2}$ capture does not systematically include biogenic and atmospheric $\mathrm{CO}_{2}$, and the modeling of $\mathrm{CO}_{2}$ utilization mainly addresses the production of fuels and chemicals while leaving aside other key utilizations for industry. Moreover, CCU should be further explored at the global level.

Consequently, decision-making in favor of CCU seems to be hazardous at this point in time. As $\mathrm{CO}_{2}$ utilization has been demonstrated to be an immature technology currently more suited to the medium 
term, we believe that the research modeling community still has time to study the matter of CCU in all of its complexity before advising decision-makers to gamble on CCU with major investment plans.

Such models can only be developed if the scientific community focuses on the economic and environmental quantification of the performance of $\mathrm{CO}_{2}$ utilization processes. We therefore call for deeper research to produce LCA and TEA studies on the range of options available for $\mathrm{CO}_{2}$ utilization. Finally, this paper provides references for CCU modelers in search of data and recommends good practices and further helpful developments in CCU modeling.

\section{CRediT author statement}

Lucas Desport: Conceptualization, Methodology, Investigation, Visualization, Writing - Original Draft, Writing - Review \& Editing. Sandrine Selosse: Conceptualization, Supervision, Writing Review \& Editing.

\section{Acknowledgement}

This research is funded by TotalEnergies and the Ministry of Higher Education and Research as part of a doctoral program (CIFRE). This work is also supported by the Chair Modeling for sustainable development, driven by MINES ParisTech and École des Ponts ParisTech, supported by ADEME, EDF, GRTgaz, RTE, SCHNEIDER ELECTRIC, TotalEnergies and the French Ministry of Ecological and Solidarity Transition. The views expressed in the reports or any public documents linked to the research program are attributable only to the authors in their personal capacity and not to the funder.

\section{References}

ACEA, 2021. Euro Standards | ACEA - European Automobile Manufacturers' Association [WWW Document]. URL https://www.acea.be/industry-topics/tag/category/euro-standards (accessed 4.29.21).

Al-Alawi, B., Cavallari, G., Cindric, H., Gargallo, M., Hegazy, N., Saqib, S., Shaka, H., Tibi, G., 2020. State of Play for Cicular Built Environment in Gulf Cooperation Council.

Algehed, J., Wirsenius, S., Jönsson, J., 2009. Modelling energy efficiency and carbon dioxide emissions in energy-intensive industry under stringent $\mathrm{CO} 2$ policies: comparison of topdown and bottom-up approaches and evaluation of usefulness to policy makers 11.

Alper, E., Yuksel Orhan, O., 2017. CO2 utilization: Developments in conversion processes. Petroleum, Carbon Capture and Storage (CCUS) 3, 109-126. https://doi.org/10.1016/j.pet/m.2016.11.003

Al-Sadoun, A., 2019. From Waste to Value: The GCC Chemical Industry's Contribution to Circular Economy. GPCA. URL https://www.gpca.org.ae/2019/03/05/from-waste-to-value-the-gccchemical-industrys-contribution-to-circular-economy/ (accessed 5.12.21).

Al-Saidi, M., Das, P., Saadaoui, I., 2021. Circular Economy in Basic Supply: Framing the Approach for the Water and Food Sectors of the Gulf Cooperation Council Countries. Sustain. Prod. Consum. 27, 1273-1285. https://doi.org/10.1016/j.spc.2021.03.004

Ampelli, C., Perathoner, S., Centi, G., 2015. CO2 utilization: an enabling element to move to a resource- and energy-efficient chemical and fuel production. Philos. Trans. R. Soc. Math. Phys. Eng. Sci. 373, 20140177. https://doi.org/10.1098/rsta.2014.0177

Aresta, M., Dibenedetto, A., Angelini, A., 2013. The changing paradigm in CO2 utilization. J. CO2 Util. 3-4, 65-73. https://doi.org/10.1016/j.jcou.2013.08.001

Armstrong, K., Styring, P., 2015. Assessing the Potential of Utilization and Storage Strategies for PostCombustion $\mathrm{CO} 2$ Emissions Reduction. Front. Energy Res. 3. https://doi.org/10.3389/fenrg.2015.00008 
Assen, N. von der, Bardow, A., 2014. Life cycle assessment of polyols for polyurethane production using $\mathrm{CO} 2$ as feedstock: insights from an industrial case study. Green Chem. 16, 3272-3280. https://doi.org/10.1039/C4GC00513A

Assoumou, E., 2006. Modélisation MARKAL pour la planification énergétique long terme dans le contexte français (phdthesis). École Nationale Supérieure des Mines de Paris.

Assoumou, E., Ghersi, F., Hourcade, J.C., Jun, L., Maïzi, N., Selosse, S., 2018. Reconciling top-down and bottom-up energy/economy models: a case of TIAM-FR and IMACLIM-R 39.

Bazzanella, A.M., Ausfelder, F., 2017. Low Carbon Energy and Feedstock for the European Chemical Industry DECHEMA Gesellschaft für Chemische Technik, 168.

Blanco, H., Nijs, W., Ruf, J., Faaij, A., 2018a. Potential of Power-to-Methane in the EU energy transition to a low carbon system using cost optimization. Appl. Energy 232, 323-340. https://doi.org/10.1016/j.apenergy.2018.08.027

Blanco, H., Nijs, W., Ruf, J., Faaij, A., 2018b. Potential for hydrogen and Power-to-Liquid in a lowcarbon EU energy system using cost optimization. Appl. Energy 232, 617-639. https://doi.org/10.1016/j.apenergy.2018.09.216

Bogdanov, D., Farfan, J., Sadovskaia, K., Aghahosseini, A., Child, M., Gulagi, A., Oyewo, A.S., de Souza Noel Simas Barbosa, L., Breyer, C., 2019. Radical transformation pathway towards sustainable electricity via evolutionary steps. Nat. Commun. 10, 1077. https://doi.org/10.1038/s41467-019-08855-1

Böhringer, C., Rutherford, T.F., 2009. Integrated assessment of energy policies: Decomposing topdown and bottom-up. J. Econ. Dyn. Control 33, 1648-1661. https://doi.org/10.1016/j.jedc.2008.12.007

Bui, M., Adjiman, C.S., Bardow, A., Anthony, E.J., Boston, A., Brown, S., Fennell, P.S., Fuss, S., Galindo, A., Hackett, L.A., Hallett, J.P., Herzog, H.J., Jackson, G., Kemper, J., Krevor, S., Maitland, G.C., Matuszewski, M., Metcalfe, I.S., Petit, C., Puxty, G., Reimer, J., Reiner, D.M., Rubin, E.S., Scott, S.A., Shah, N., Smit, B., Trusler, J.P.M., Webley, P., Wilcox, J., Mac Dowell, N., 2018. Carbon capture and storage (CCS): the way forward. Energy Environ. Sci. 11, 1062-1176. https://doi.org/10.1039/C7EE02342A

Butnar, I., Cronin, J., Pye, S., 2020. Review of Carbon Capture Utilisation and Carbon Capture and Storage in future EU decarbonisation scenarios. Final Rep. 57.

Capros, P., Siskos, P., 2011. PRIMES-TREMOVE transport model v3 - Model description.

Capros, P., Zazias, G., Evangelopoulou, S., Kannavou, M., Fotiou, T., Siskos, P., De Vita, A., Sakellaris, K., 2019. Energy-system modelling of the EU strategy towards climate-neutrality. Energy Policy 134, 110960. https://doi.org/10.1016/j.enpol.2019.110960

Carapellucci, R., Giordano, L., 2020. Steam, dry and autothermal methane reforming for hydrogen production: A thermodynamic equilibrium analysis. J. Power Sources 469, 228391. https://doi.org/10.1016/j.jpowsour.2020.228391

Centi, G., Perathoner, S., Salladini, A., Iaquaniello, G., 2020. Economics of CO2 Utilization: A Critical Analysis. Front. Energy Res. 8. https://doi.org/10.3389/fenrg.2020.567986

Chauvy, R., Meunier, N., Thomas, D., De Weireld, G., 2019. Selecting emerging CO2 utilization products for short- to mid-term deployment. Appl. Energy 236, 662-680. https://doi.org/10.1016/j.apenergy.2018.11.096

Chen, Paltsev, S., Reilly, J.M., Karplus, V., Gurgel, A., Winchester, N., Kishimoto, P., Blanc, E., Babiker, M., 2017. The MIT Economic Projection and Policy Analysis (EPPA) Model: Version 5.

Climate Action Tracker, 2020. China going carbon neutral before 2060 would lower warming projections by around 0.2 to 0.3 degrees C | Climate Action Tracker [WWW Document]. URL https://climateactiontracker.org/press/china-carbon-neutral-before-2060-would-lowerwarming-projections-by-around-2-to-3-tenths-of-a-degree/ (accessed 10.12.20).

CO2 Utilization: A Look Ahead [WWW Document], 2017. . Cent. Clim. Energy Solut. URL https://www.c2es.org/document/co2-utilization-a-look-ahead/ (accessed 8.7.20). 
Cruz, T.T. da, Perrella Balestieri, J.A., de Toledo Silva, J.M., Vilanova, M.R.N., Oliveira, O.J., Ávila, I., 2021. Life cycle assessment of carbon capture and storage/utilization: From current state to future research directions and opportunities. Int. J. Greenh. Gas Control 108, 103309. https://doi.org/10.1016/j.ijggc.2021.103309

Cuéllar-Franca, R., García-Gutiérrez, P., Dimitriou, I., Elder, R.H., Allen, R.W.K., Azapagic, A., 2019. Utilising carbon dioxide for transport fuels: The economic and environmental sustainability of different Fischer-Tropsch process designs. Appl. Energy 253, 113560. https://doi.org/10.1016/j.apenergy.2019.113560

Cuéllar-Franca, R.M., Azapagic, A., 2015. Carbon capture, storage and utilisation technologies: A critical analysis and comparison of their life cycle environmental impacts. J. CO2 Util. 9, 82102. https://doi.org/10.1016/j.jcou.2014.12.001

Cunha, B.S.L., Garaffa, R., Gurgel, A., 2020. TEA Model Documentation (Working Paper). FGV.

de Pee, A., Pinner, D., Roelofsen, O., Somers, K., Speelman, E., Witteveen, M., 2018. Decarbonization of industrial sectors -The next frontier.pdf. McKinsey\&Company.

Dutta, A., Farooq, S., Karimi, I.A., Khan, S.A., 2017. Assessing the potential of CO2 utilization with an integrated framework for producing power and chemicals. J. CO2 Util. 19, 49-57. https://doi.org/10.1016/j.jcou.2017.03.005

ETSAP, 2021. IEA-ETSAP | Times [WWW Document]. URL https://iea-etsap.org/index.php/etsaptools/model-generators/times (accessed 7.5.21).

European Commission, 2016. 2050 long-term strategy [WWW Document]. Clim. Action - Eur. Comm. URL https://ec.europa.eu/clima/policies/strategies/2050_en (accessed 10.12.20).

Fajardy, M., Morris, J., Gurgel, A., Herzog, H., Mac Dowell, N., Paltsev, S., 2021. The economics of bioenergy with carbon capture and storage (BECCS) deployment in a $1.5^{\circ} \mathrm{C}$ or $2{ }^{\circ} \mathrm{C}$ world. Glob. Environ. Change 68, 102262. https://doi.org/10.1016/j.gloenvcha.2021.102262

Farell, J., 2018. The role of industrial carbon capture and storage in emissions mitigation. Massachussets Institute of Technology, Boston, MA, USA.

Farfan, J., Fasihi, M., Breyer, C., 2019. Trends in the global cement industry and opportunities for long-term sustainable CCU potential for Power-to-X. J. Clean. Prod. 217, 821-835. https://doi.org/10.1016/j.jclepro.2019.01.226

Fasihi, M., Bogdanov, D., Breyer, C., 2017. Long-Term Hydrocarbon Trade Options for the Maghreb Region and Europe-Renewable Energy Based Synthetic Fuels for a Net Zero Emissions World. Sustainability 9, 306. https://doi.org/10.3390/su9020306

Fasihi, M., Efimova, O., Breyer, C., 2019. Techno-economic assessment of $\mathrm{CO} 2$ direct air capture plants. J. Clean. Prod. 224, 957-980. https://doi.org/10.1016/j.jclepro.2019.03.086

Fuss, S., Lamb, W.F., Callaghan, M.W., Hilaire, J., Creutzig, F., Amann, T., Beringer, T., de Oliveira Garcia, W., Hartmann, J., Khanna, T., Luderer, G., Nemet, G.F., Rogelj, J., Smith, P., Vicente, J.L.V., Wilcox, J., del Mar Zamora Dominguez, M., Minx, J.C., 2018. Negative emissions-Part 2: Costs, potentials and side effects. Environ. Res. Lett. 13, 063002. https://doi.org/10.1088/1748-9326/aabf9f

Gabrielli, P., Gazzani, M., Mazzotti, M., 2020. The Role of Carbon Capture and Utilization, Carbon Capture and Storage, and Biomass to Enable a Net-Zero-CO2 Emissions Chemical Industry. Ind. Eng. Chem. Res. 59, 7033-7045. https://doi.org/10.1021/acs.iecr.9b06579

Gerresten, I., 2020. South Korea formally commits to cutting emissions to net zero by 2050 [WWW Document]. Clim. Home News. URL https://www.climatechangenews.com/2020/10/28/south-korea-formally-commits-cuttingemissions-net-zero-2050/ (accessed 11.10.20).

Ghiat, I., Al-Ansari, T., 2021. A review of carbon capture and utilisation as a CO2 abatement opportunity within the EWF nexus. J. CO2 Util. 45, 101432.

https://doi.org/10.1016/j.jcou.2020.101432 
Hanna, R., Abdulla, A., Xu, Y., Victor, D.G., 2021. Emergency deployment of direct air capture as a response to the climate crisis. Nat. Commun. 12, 368. https://doi.org/10.1038/s41467-02020437-0

Helgesen, P.I., 2013. Top-down and Bottom-up: Combining energy system models and macroeconomic general equilibrium models.pdf.

Hepburn, C., Adlen, E., Beddington, J., Carter, E.A., Fuss, S., Dowell, N.M., Minx, J.C., Smith, P., Williams, C.K., 2019. The technological and economic prospects for $\mathrm{CO} 2$ utilization and removal. Nature 575, 87-97. https://doi.org/10.1038/s41586-019-1681-6

Hourcade, J.-C., Jaccard, M., Bataille, C., Ghersi, F., 2006. Hybrid Modeling: New Answers to Old Challenges Introduction to the Special Issue of The Energy Journal. Energy J. SI2006. https://doi.org/10.5547/ISSN0195-6574-EJ-VoISI2006-NoSI2-1

Huang, C.-H., Tan, C.-S., 2014. A Review: CO2 Utilization. Aerosol Air Qual. Res. 14, 480-499. https://doi.org/10.4209/aaqr.2013.10.0326

IAMC-Documentation contributors, 2021. IAMC wiki [WWW Document]. URL https://www.iamcdocumentation.eu/index.php?title=IAMC_wiki\&oldid=14740 (accessed 7.5.21).

ICEF, 2016. Global Roadmap for implementing CO2 utilization. ICEF.

IEA, 2021. Net Zero by 2050 - A Roadmap for the Global Energy Sector 224.

IEA, 2020. CCUS in clean energy transitions. Energy Technol. Perspect. 174.

IEA, 2019a. Transforming Industry through CCUS 62.

IEA, 2019b. Putting CO2 to Use.

IEA, 2019c. Exploring Clean Energy Pathways: The role of CO2 storage 105.

IOGP, 2021. Map of global CCUS projects. IOGP Publ. Libr. URL

https://www.iogp.org/bookstore/product/map-of-global-ccs-projects/ (accessed 10.12.21).

IOGP, 2019. The potential for CCS and CCU in Europe 47.

IPCC, 2018. Global warming of $1.5^{\circ} \mathrm{C}$. An IPCC Special Report on the impacts of global warming of $1.5^{\circ} \mathrm{C}$ above pre-industrial levels and related global greenhouse gas emission pathways, in the context of strengthening the global response to the threat of climate change, sustainable development, and efforts to eradicate poverty.

IRENA, 2020. Green hydrogen cost reduction: Scaling up electrolysers to meet the $1.5 \mathrm{C}$ climate goal 106.

Irlam, L., 2017. Global CCS Institute : Global Costs of Carbon Capture and Storage. Global CCS Institute.

Kapetaki, Z., Miranda Barbosa, E., European Commission, Joint Research Centre, 2019. Carbon capture utilisation and storage: technology development report.

Kätelhön, A., Meys, R., Deutz, S., Suh, S., Bardow, A., 2019. Climate change mitigation potential of carbon capture and utilization in the chemical industry. Proc. Natl. Acad. Sci. 116, 1118711194. https://doi.org/10.1073/pnas.1821029116

Keppo, I., Butnar, I., Bauer, N., Caspani, M., Edelenbosch, O., Emmerling, J., Fragkos, P., Guivarch, C., Harmsen, M., Lefèvre, J., Gallic, T.L., Leimbach, M., McDowall, W., Mercure, J.-F., Schaeffer, R., Trutnevyte, E., Wagner, F., 2021. Exploring the possibility space: taking stock of the diverse capabilities and gaps in integrated assessment models. Environ. Res. Lett. 16, 053006. https://doi.org/10.1088/1748-9326/abe5d8

Khalili, S., Rantanen, E., Bogdanov, D., Breyer, C., 2019. Global Transportation Demand Development with Impacts on the Energy Demand and Greenhouse Gas Emissions in a ClimateConstrained World. Energies 12, 3870. https://doi.org/10.3390/en12203870

Kim, D., 2021. Economies of scale and international business cycles. J. Int. Econ. 131, 103459. https://doi.org/10.1016/j.jinteco.2021.103459

Köberle, A.C., 2019. The Value of BECCS in IAMs: a Review. Curr. Sustain. Energy Rep. 6, 107-115. https://doi.org/10.1007/s40518-019-00142-3 
Leeson, D., Mac Dowell, N., Shah, N., Petit, C., Fennell, P.S., 2017. A Techno-economic analysis and systematic review of carbon capture and storage (CCS) applied to the iron and steel, cement, oil refining and pulp and paper industries, as well as other high purity sources. Int. J. Greenh. Gas Control 61, 71-84. https://doi.org/10.1016/j.ijggc.2017.03.020

Leonzio, G., Bogle, D., Foscolo, P.U., Zondervan, E., 2020. Optimization of CCUS supply chains in the UK: A strategic role for emissions reduction. Chem. Eng. Res. Des. 155, 211-228. https://doi.org/10.1016/j.cherd.2020.01.002

Leonzio, G., Foscolo, P.U., Zondervan, E., 2019. An outlook towards 2030: Optimization and design of a CCUS supply chain in Germany. Comput. Chem. Eng. 125, 499-513. https://doi.org/10.1016/j.compchemeng.2019.04.001

Leonzio, G., Zondervan, E., 2020. Analysis and optimization of carbon supply chains integrated to a power to gas process in Italy. J. Clean. Prod. 269, 122172. https://doi.org/10.1016/j.jclepro.2020.122172

Loulou, R., Labriet, M., 2008. ETSAP-TIAM: the TIMES integrated assessment model Part I: Model structure. Comput. Manag. Sci. 5, 7-40. https://doi.org/10.1007/s10287-007-0046-z

Luna, P.D., Hahn, C., Higgins, D., Jaffer, S.A., Jaramillo, T.F., Sargent, E.H., 2019. What would it take for renewably powered electrosynthesis to displace petrochemical processes? Science 364. https://doi.org/10.1126/science.aav3506

Mac Dowell, N., Fennell, P.S., Shah, N., Maitland, G.C., 2017. The role of $\mathrm{CO} 2$ capture and utilization in mitigating climate change. Nat. Clim. Change 7, 243-249. https://doi.org/10.1038/nclimate3231

Marchese, M., Buffo, G., Santarelli, M., Lanzini, A., 2021. CO2 from direct air capture as carbon feedstock for Fischer-Tropsch chemicals and fuels: Energy and economic analysis. J. CO2 Util. 46, 101487. https://doi.org/10.1016/j.jcou.2021.101487

Mauler, L., Duffner, F., Leker, J., 2021. Economies of scale in battery cell manufacturing: The impact of material and process innovations. Appl. Energy 286, 116499. https://doi.org/10.1016/j.apenergy.2021.116499

Morris, J., Farrell, J., Kheshgi, H., Thomann, H., Chen, H., Paltsev, S., Herzog, H., 2019. Representing the costs of low-carbon power generation in multi-region multi-sector energy-economic models. Int. J. Greenh. Gas Control 87, 170-187. https://doi.org/10.1016/j.ijggc.2019.05.016

Mustafa, A., Lougou, B.G., Shuai, Y., Wang, Z., Tan, H., 2020. Current technology development for CO2 utilization into solar fuels and chemicals: A review. J. Energy Chem. 49, 96-123. https://doi.org/10.1016/j.jechem.2020.01.023

Nakamura, A., Yanagi, K., Komatsu, E., 2019. Toward a Regional Approach to Climate Change Mitigation Policies: The Roles of and Barriers to Policy and Legal Framework to Expand Potential Opportunities for Carbon Capture, Utilisation and Storage (CCUS) in the Asian Pacific Region (SSRN Scholarly Paper No. ID 3374363). Social Science Research Network, Rochester, NY.

Norton, M., Baldi, A., Buda, V., Carli, B., Cudlin, P., Jones, M.B., Korhola, A., Michalski, R., Novo, F., Oszlányi, J., Santos, F.D., Schink, B., Shepherd, J., Vet, L., Walloe, L., Wijkman, A., 2019. Serious mismatches continue between science and policy in forest bioenergy. GCB Bioenergy 11, 1256-1263. https://doi.org/10.1111/gcbb.12643

Olah, G.A., Goeppert, A., Prakash, G.K.S., 2009. Chemical Recycling of Carbon Dioxide to Methanol and Dimethyl Ether: From Greenhouse Gas to Renewable, Environmentally Carbon Neutral Fuels and Synthetic Hydrocarbons. J. Org. Chem. 74, 487-498. https://doi.org/10.1021/jo801260f

Pérez-Fortes, M., Schöneberger, J.C., Boulamanti, A., Tzimas, E., 2016. Methanol synthesis using captured $\mathrm{CO} 2$ as raw material: Techno-economic and environmental assessment. Appl. Energy 161, 718-732. https://doi.org/10.1016/j.apenergy.2015.07.067 
Prina, M.G., Manzolini, G., Moser, D., Nastasi, B., Sparber, W., 2020. Classification and challenges of bottom-up energy system models - A review. Renew. Sustain. Energy Rev. 129, 109917. https://doi.org/10.1016/j.rser.2020.109917

Quarton, C.J., Samsatli, S., 2020. The value of hydrogen and carbon capture, storage and utilisation in decarbonising energy: Insights from integrated value chain optimisation. Appl. Energy 257, 113936. https://doi.org/10.1016/j.apenergy.2019.113936

Ravikumar, D., Keoleian, G.A., Miller, S.A., Sick, V., 2021. Assessing the Relative Climate Impact of Carbon Utilization for Concrete, Chemical, and Mineral Production. Environ. Sci. Technol. acs.est.1c01109. https://doi.org/10.1021/acs.est.1c01109

Rutherford, T.F., 2009. Lecture Notes on CES Functions 22.

Sandalow, D., Friedmann, J., Aines, R., McCormick, C., McCoy, S., Stolaroff, J., 2019. ICEF Industrial heat decarbonisation roadmap.pdf. ICEF.

Sathaye, J., Sanstad, A.H., 2004. Bottom-up energy modeling. Encycl. Energy 1.

Schmidt, O., Gambhir, A., Staffell, I., Hawkes, A., Nelson, J., Few, S., 2017. Future cost and performance of water electrolysis: An expert elicitation study. Int. J. Hydrog. Energy 42, 30470-30492. https://doi.org/10.1016/j.ijhydene.2017.10.045

Selosse, S., 2019. Bioenergy with carbon capture and storage: how carbon storage and biomass resources potentials can impact the development of the BECCS, in: Bioenergy with Carbon Capture and Storage. Elsevier, pp. 237-256. https://doi.org/10.1016/B978-0-12-8162293.00012-0

Siskos, P., Capros, P., De Vita, A., 2015. CO2 and energy efficiency car standards in the EU in the context of a decarbonisation strategy: A model-based policy assessment. Energy Policy 84, 22-34. https://doi.org/10.1016/j.enpol.2015.04.024

Slade, R., Di Lucia, L., Adams, P., 2018. Chapter 2 - How Policy Makers Learned to Start Worrying and Fell Out of Love With Bioenergy, in: Thornley, P., Adams, P. (Eds.), Greenhouse Gas Balances of Bioenergy Systems. Academic Press, pp. 11-28. https://doi.org/10.1016/B978-0-08101036-5.00002-1

Subramanian, S., Athira, K.R., Anbu Kulandainathan, M., Senthil Kumar, S., Barik, R.C., 2020. New insights into the electrochemical conversion of $\mathrm{CO} 2$ to oxalate at stainless steel $304 \mathrm{~L}$ cathode. J. CO2 Util.

Takeshita, T., 2013. A cost-optimal scenario of $\mathrm{CO} 2$ sequestration in a carbon-constrained world through to 2050. Nat. Sci. 5, 313-319. https://doi.org/10.4236/ns.2013.52A043

Tapia, J.F.D., Lee, J.-Y., Ooi, R.E.H., Foo, D.C.Y., Tan, R.R., 2018. A review of optimization and decision-making models for the planning of $\mathrm{CO} 2$ capture, utilization and storage (CCUS) systems. Sustain. Prod. Consum. 13, 1-15. https://doi.org/10.1016/j.spc.2017.10.001

Tapia, J.F.D., Lee, J.-Y., Ooi, R.E.H., Foo, D.C.Y., Tan, R.R., 2014. CO2 Allocation for Scheduling Enhanced Oil Recovery (EOR) Operations with Geological Sequestration Using Discrete-time Optimization. Energy Procedia, International Conference on Applied Energy, ICAE2014 61, 595-598. https://doi.org/10.1016/j.egypro.2014.11.1189

Teske, S. (Ed.), 2019. Achieving the Paris Climate Agreement Goals: Global and Regional $100 \%$ Renewable Energy Scenarios with Non-energy GHG Pathways for $+1.5^{\circ} \mathrm{C}$ and $+2^{\circ} \mathrm{C}$. Springer International Publishing, Cham. https://doi.org/10.1007/978-3-030-05843-2

Timperley, J., 2020. What can the world learn from New Zealand on climate? Lancet Planet. Health 4, e176-e177. https://doi.org/10.1016/S2542-5196(20)30109-1

UNFCCC, 2021. Integrated Assessment Models (IAMs) and Energy-Environment-Economy (E3) models: | UNFCCC [WWW Document]. URL https://unfccc.int/topics/mitigation/workstreams/response-measures/integratedassessment-models-iams-and-energy-environment-economy-e3-models (accessed 4.21.21).

United Nations, 2020. Climate action: UN chief encouraged by Japan's 2050 net zero pledge [WWW Document]. UN News. URL https://news.un.org/en/story/2020/10/1076132 (accessed 11.10.20). 
van Vliet, O., van den Broek, M., Turkenburg, W., Faaij, A., 2011. Combining hybrid cars and synthetic fuels with electricity generation and carbon capture and storage. Energy Policy 39, 248-268. https://doi.org/10.1016/j.enpol.2010.09.038

Williams, J.H., Jones, R.A., Haley, B., Kwok, G., Hargreaves, J., Farbes, J., Torn, M.S., 2021. CarbonNeutral Pathways for the United States. AGU Adv. 2, e2020AV000284.

https://doi.org/10.1029/2020AV000284

Yoshida, M., Ogawa, T., Imamura, Y., Ishihara, K.N., 2021. Economies of scale in ammonia synthesis loops embedded with iron- and ruthenium-based catalysts. Int. J. Hydrog. Energy. https://doi.org/10.1016/j.ijhydene.2020.12.081

Zhang, S., Zhuang, Y., Tao, R., Liu, L., Zhang, L., Du, J., 2020. Multi-objective optimization for the deployment of carbon capture utilization and storage supply chain considering economic and environmental performance. J. Clean. Prod. 270, 122481.

https://doi.org/10.1016/j.jclepro.2020.122481 